\title{
Field Gemology: Building a ReseARCH COLLECTION AND UNDERSTANDING THE DeVElopMent OF GeM DePOSITS
}

Wim Vertriest, Aaron C. Palke, and Nathan D. Renfro

GIA's field gemology program was established in late 2008 to support research on geographic origin determination of colored gemstones. By building and maintaining an extensive collection of gem materials with known origins, GIA's research scientists have been able to study and analyze rubies, sapphires, emeralds, and other gemstones using the best available reference samples. This has led to improved origin determination services while supporting numerous research and education projects. To date the collection has accumulated during more than 95 field expeditions on six continents and currently includes more than 22,000 samples. GIA's field gemology efforts require a thorough understanding of the gem trade, including the evolution of gemstone deposits and the development of treatments. It is important to recognize potential new deposits and gemstone enhancement procedures immediately because they can change rapidly and leave a lasting impact on the trade. Field expeditions also involve documenting the mines and local conditions. These factors provide context for the gemstones and are becoming increasingly important in the eyes of the public.

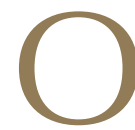
ver the last decade, GIA has invested considerable resources in determining the geographic origin of certain gemstones. The field gemology program plays an essential role in these studies. Its mission is to build, maintain, and expand a reliable reference collection of scientific samples (figure 1). These stones are used for research by GIA's gemologists and research scientists.

This article explains the challenges of geographic origin research, sample collection, and the current state of GIA's colored stone reference collection. The development of gemstone deposits is also discussed, and an overview is provided of the most important localities for which GIA offers origin determination.

\section{THE CRITICAL FACTOR IN GEOGRAPHIC ORIGIN RESEARCH}

In recent years, the gem and jewelry trade has come to place a premium on the geographic origin of highvalue gemstones. This has expanded the traditional

See end of article for About the Authors and Acknowledgments.

Gems \& Gemology, Vol. 55, No. 4, pp. 490-511,

http://dx.doi.org/10.5741/GEMS.55.4.490

(C) 2019 Gemological Institute of America role of laboratories, which is mainly gem identification and detection of treatments and synthetics, to also include geographic origin determination of certain gem species.

Geographic origin determination of colored gemstones relies heavily on advanced research. In a mod-

\section{In Brief}

- GIA's colored stone reference collection is one of the largest and best-documented collections of its kind.

- A thorough understanding of the colored stone market and available materials is required when building a reference database.

- Gem-producing areas are constantly changing: Field gemologists need to follow up on old and new sources.

- Apart from maintaining the colored stone research collection, GIA's field gemology department is responsible for documenting the mining and trading environment.

ern gemological lab, advanced analytical techniques and highly trained scientists are irreplaceable. But the work of a brilliant team with the most sophisticated equipment is irrelevant if the reference mate- 


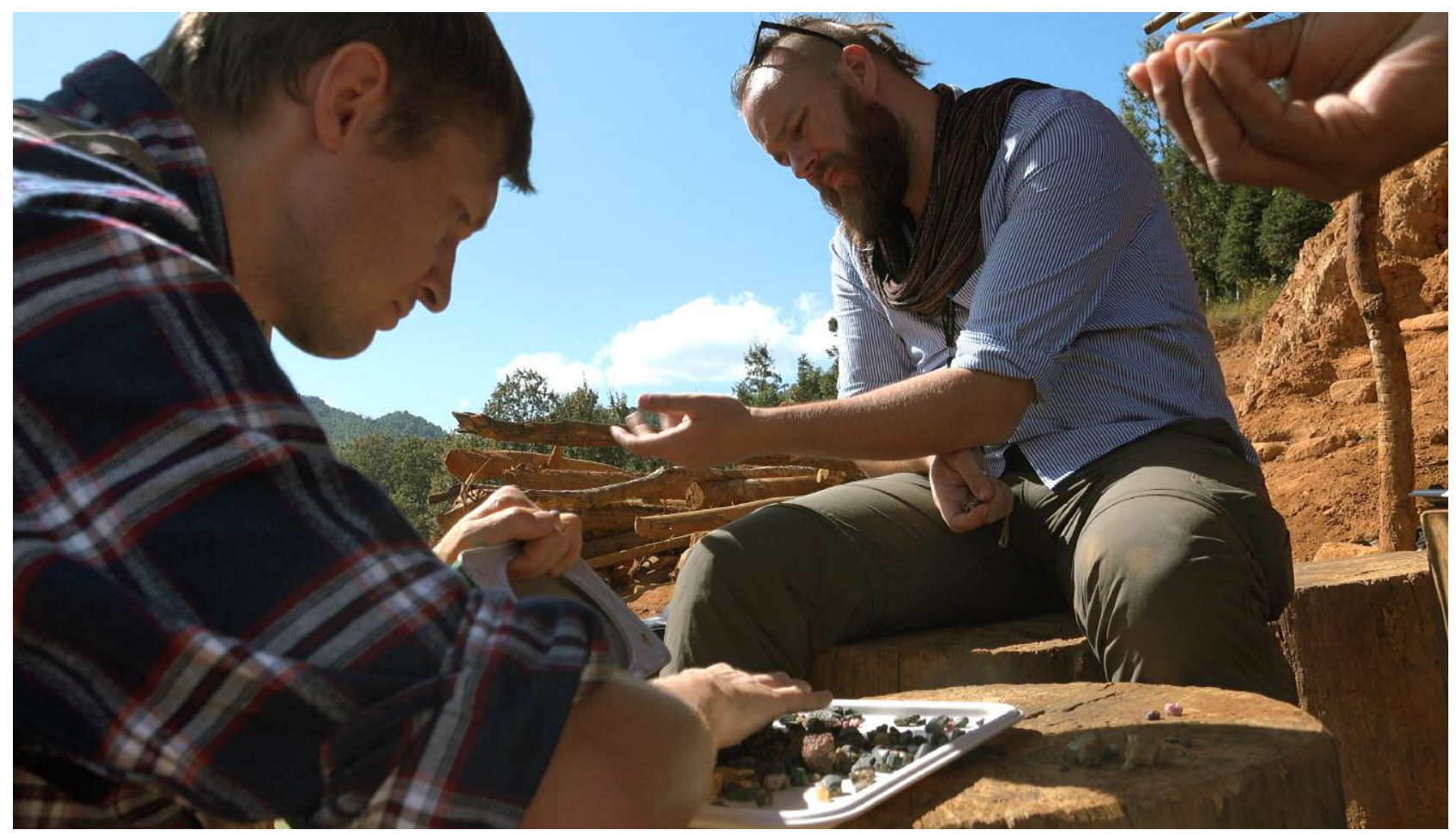

Figure 1. Aaron Palke (left) and Wim Vertriest sort through gem gravel in Mogok, Myanmar, in December 2018. Photo by Kevin Schumacher.

rial is not reliable. Dependable research samples are the critical factor to ensure solid research for geographic origin determination. The quality of the reference materials determines the quality of the data produced.

\section{WHAT MAKES A RESEARCH COLLECTION RELIABLE?}

Gemstones are small, high-value assets that are easily transportable but difficult to trace. This can lead to a lack of transparency throughout the supply chain. Procuring trustworthy samples from the trade is challenging for research institutes, especially when the trade places such high value on the results of their work. Traders might try to influence research to their own advantage by providing limited or incorrect samples.

A strong reference collection is the necessary foundation of research, but what makes a collection reliable? Naturalist and documentary filmmaker Sir David Attenborough noted that

a research library associated with collections is almost of greater importance than the objects themselves. Unless you know where it came from exactly, and when it came from exactly, you are missing a lot of very, very important information. And that information can not only come from the object itself, but from the circumstances of documentation that should accompany every scientifically collected specimen.

("Sir David Attenborough...," 2017)

Building a reliable collection requires going where the stones are, as it is unsustainable to rely solely on donations from traders. GIA's field gemology department was created to establish a reliable collection to support origin determination by collecting the samples directly. Over the last decade, the department has gathered gemstones on six continents through more than 95 expeditions.

While the ultimate goal is to collect samples in the mines (figure 2), this is not always feasible: Some mines are no longer active, and others are off limits to foreigners or pose great safety risks. This means the samples in GIA's reference collection have various degrees of reliability. GIA developed the following classification scheme, which reflects the degree of confidence for origin from high to low:

- A-type samples are mined directly by the field gemologist (figure 3). This includes sampling from the host rock in the mine, washing/panning an alluvial deposit, and the like. Naturally, these have the highest degree of reliability. 


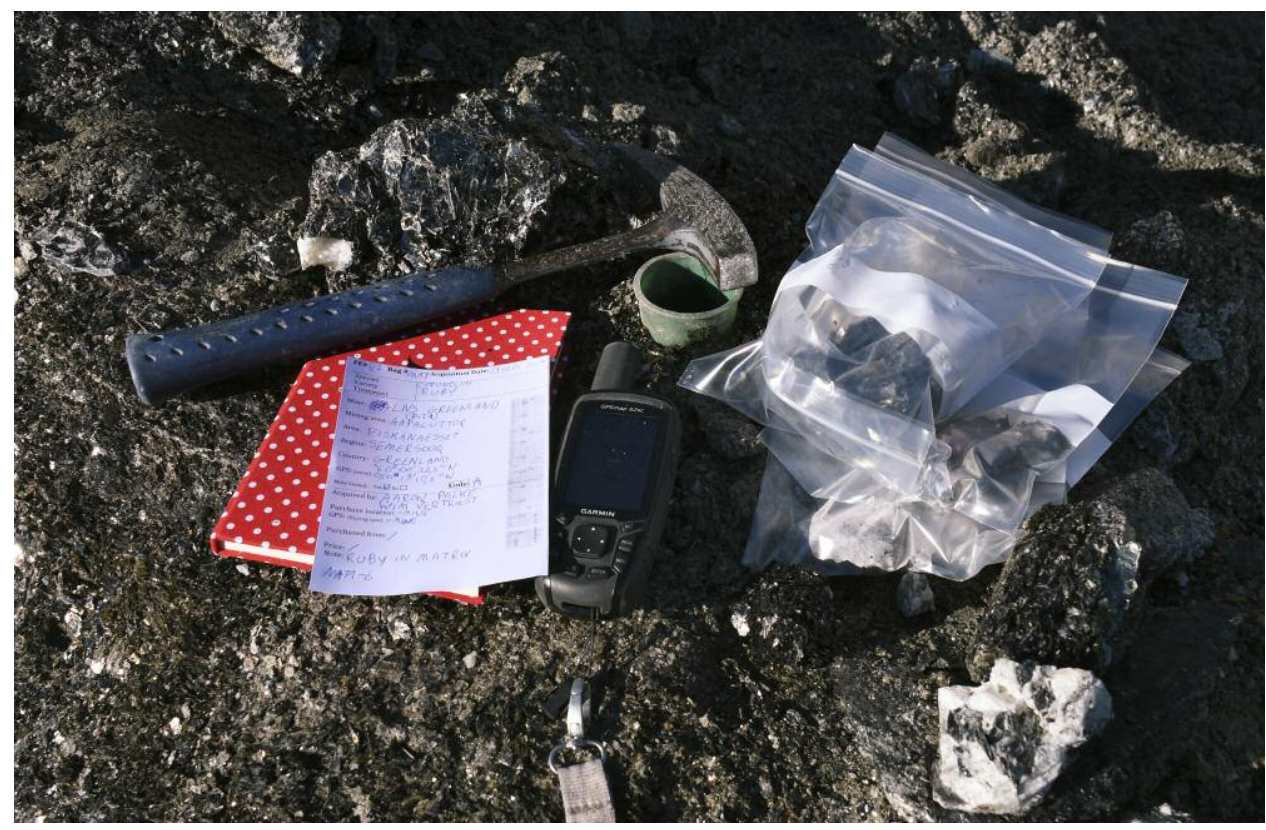

Figure 2. During GIA field expedition 87 to Greenland's ruby mines, samples were collected from the host rock using a geological hammer. The samples are individually bagged and associated data, including GPS coordinates, is immediately attached on a paper label. Photo by Wim Vertriest.

- B-type samples are collected at the mine with the field gemologist witnessing the mining process but not actively removing the stones from the ground (figure 4). Miners are naturally protective of their goods-one high-value stone that goes missing could make a huge difference in a mining operation. In many places, visitors are not allowed to touch mining equipment, sorting tables, or exposed rock faces, so B-type samples are often easier to obtain than A-type.
The most common scenario for this type of sample is where gravels are washed and concentrated on a large scale. In these operations, the washing plant is usually cleared at the end of the day. These stones still have a clearly established origin.

- C-type samples are collected at the mine but without witnessing the mining process for the specific stones (figure 5). Miners often possess gems that were mined in previous days. Arti-

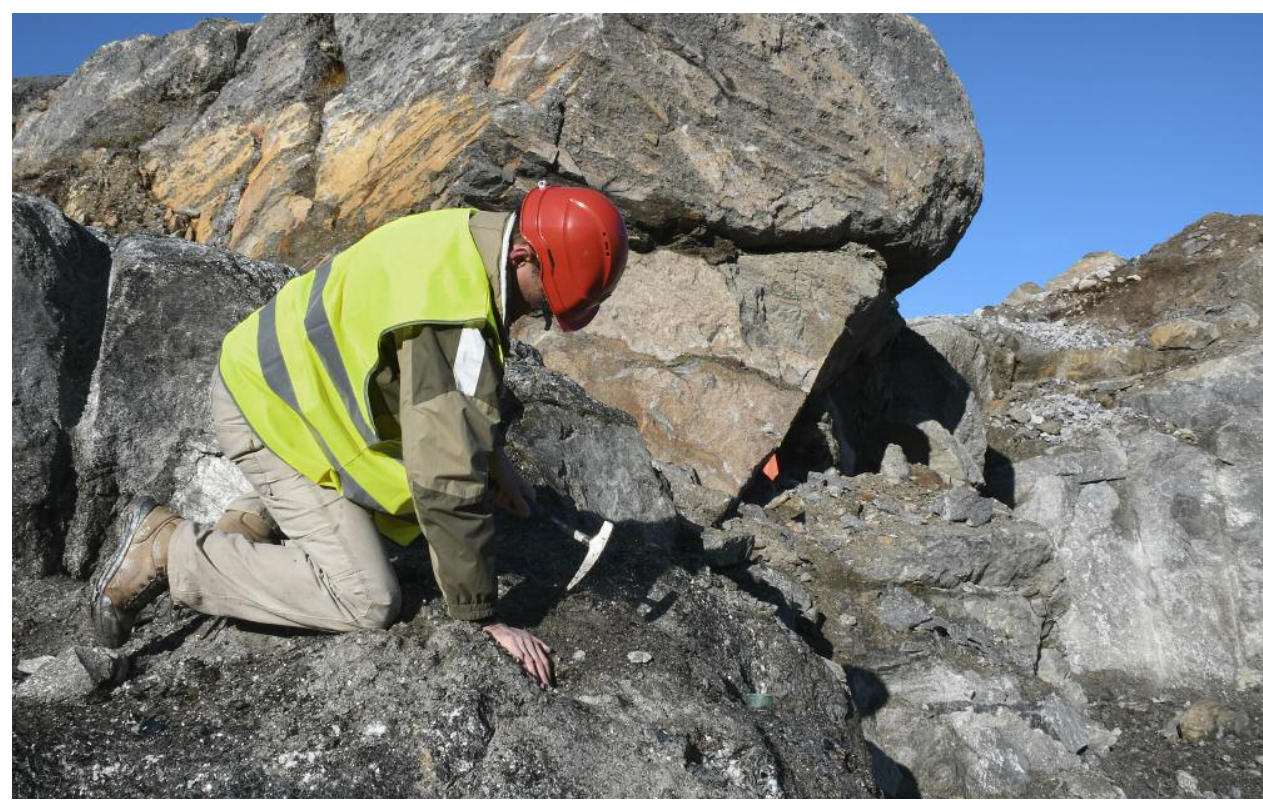

Figure 3. A-type sampling: Author AP collects ruby and pink sapphire directly from the host rock in Aappaluttoq, Greenland. Photo by Wim Vertriest. 


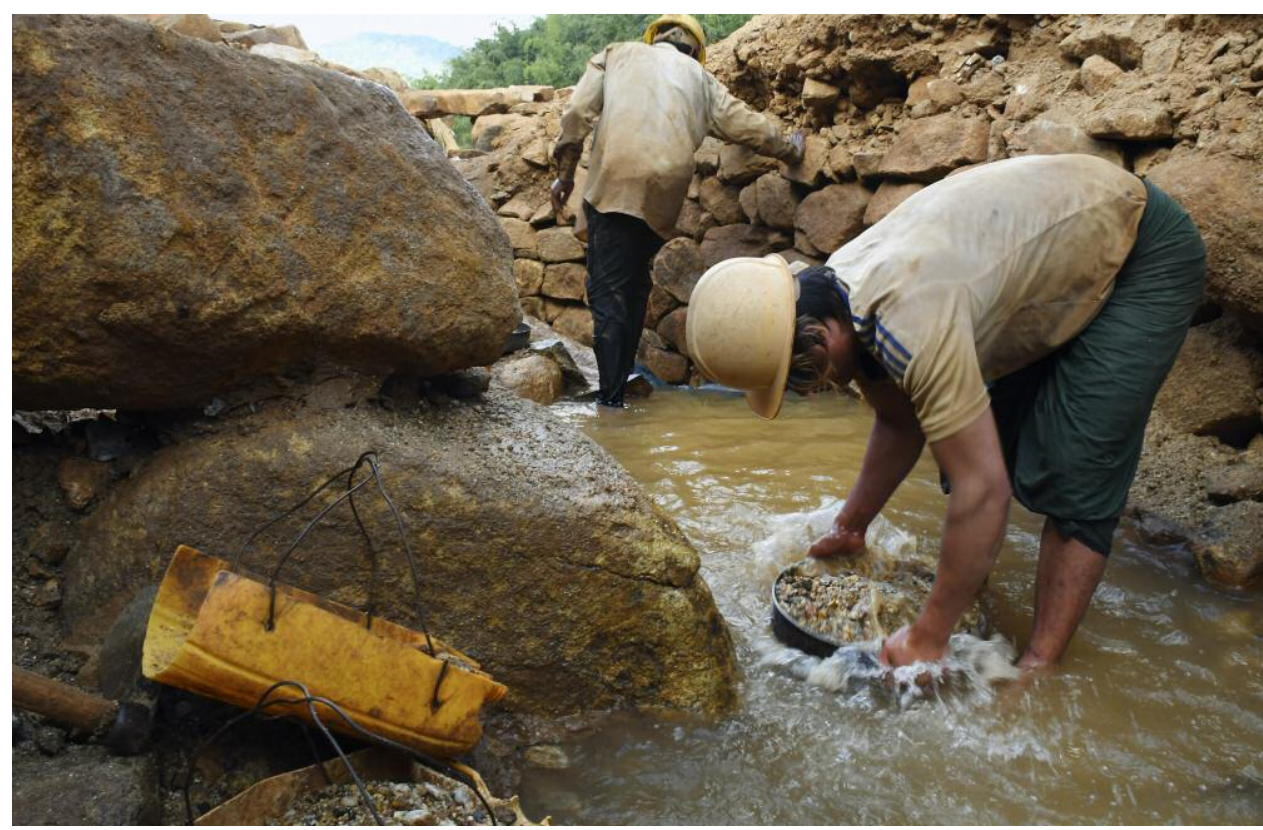

Figure 4. B-type sampling: Collecting samples from gravel that is being washed by a Burmese miner in the Kin area, west of Mogok. Photo by Wim Vertriest.

sanal miners also change working locations regularly. In these circumstances, the origin is already less certain since parcels might easily have been switched, added to, or mixed with production from multiple sites.

- D-type samples are collected from the miner but not at the mine (figure 6). Large-scale operations often have off-site headquarters where sorting, grading, and other steps take place. Artisanal miners often travel to central markets to sell their goods. Since these samples are collected off-site, the origin is less certain than that of stones obtained at the mines.

- E-type samples are purchased from dealers in the local market, often in close proximity to the mines (figure 7). The sellers have collected the material from the miners and often present stones from a mix of different miners and potentially sources. These are less reliable than stones obtained directly from the miners.

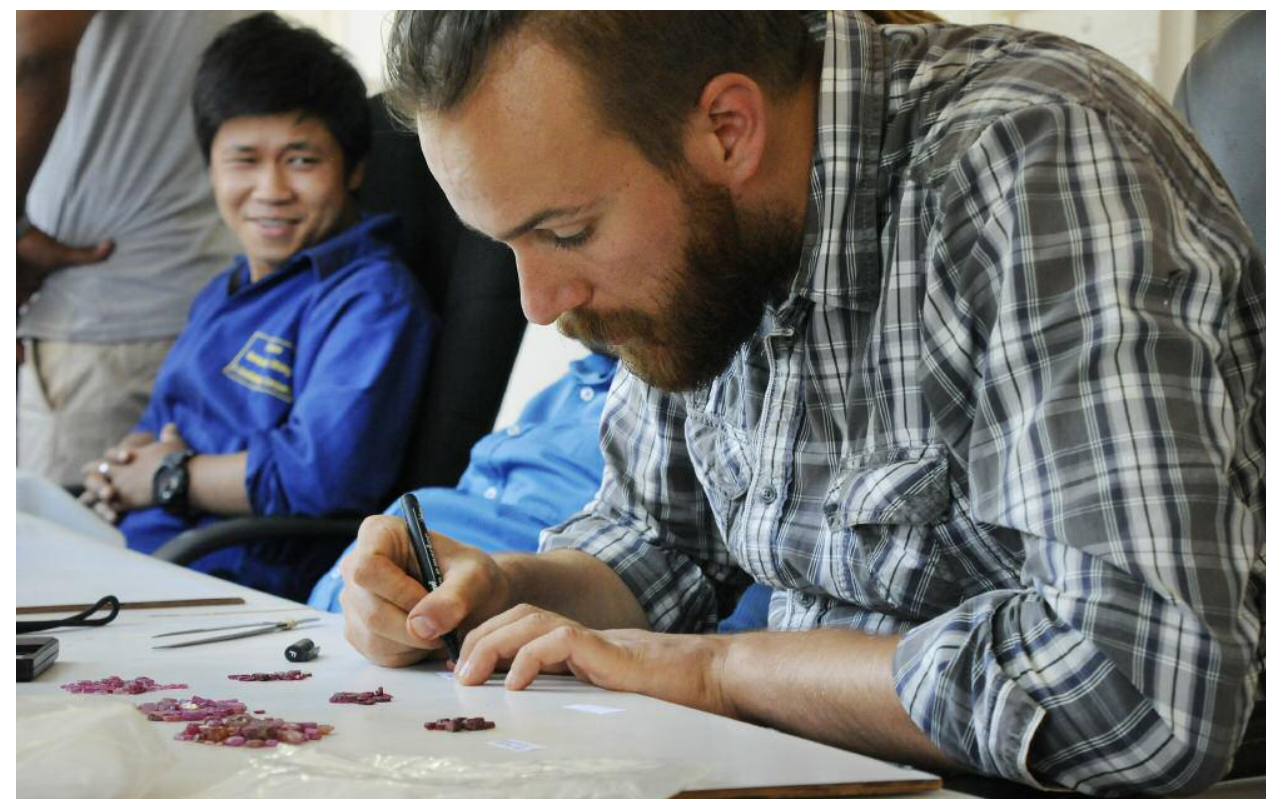

Figure 5. C-type sampling: Selecting rubies in the sorting house at Montepuez Ruby Mining's operation in Montepuez, Mozambique. Photo by M. Lemoux. 


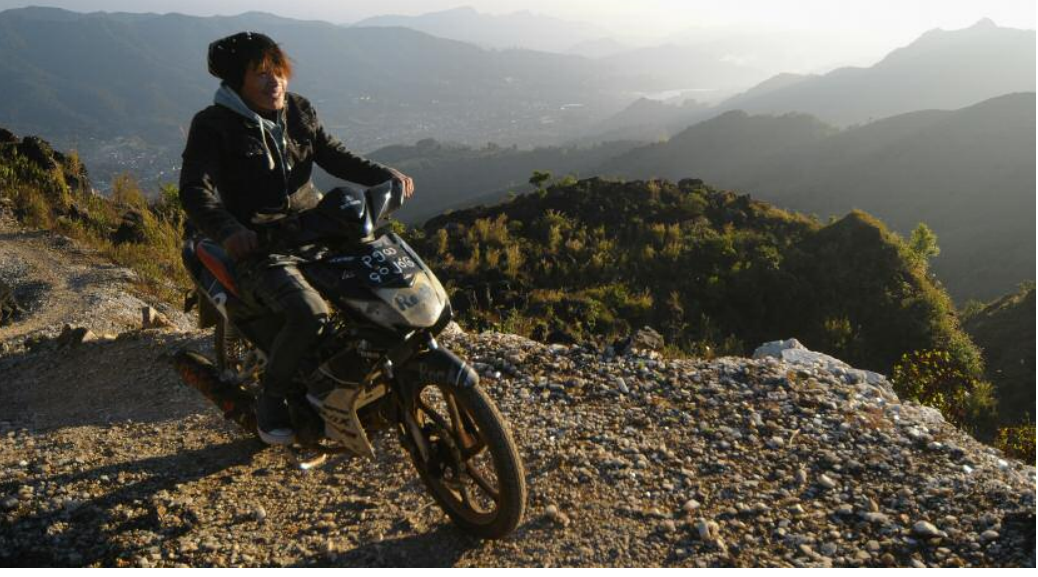

Figure 6. D-type sampling: The GIA team purchased samples from this artisanal miner along the road in Mogok, Myanmar. Every day he drives his motorbike into the mountains to work a small ruby deposit. Photo by Wim Vertriest.

- F-type samples are collected in international markets (figure 8). Gemstones are often traded in centers with a high volume of stones, where it is easy to obtain a variety of samples and spot goods that are new to the trade. These sites can be temporary, such as the Tucson and Hong Kong trade shows, or fixed trading hubs like Bangkok. Ma-

Figure 7. E-type sampling: Author WV checks blue spinel at the morning market in Luc Yen, Vietnam. Photo by Vincent Pardieu.

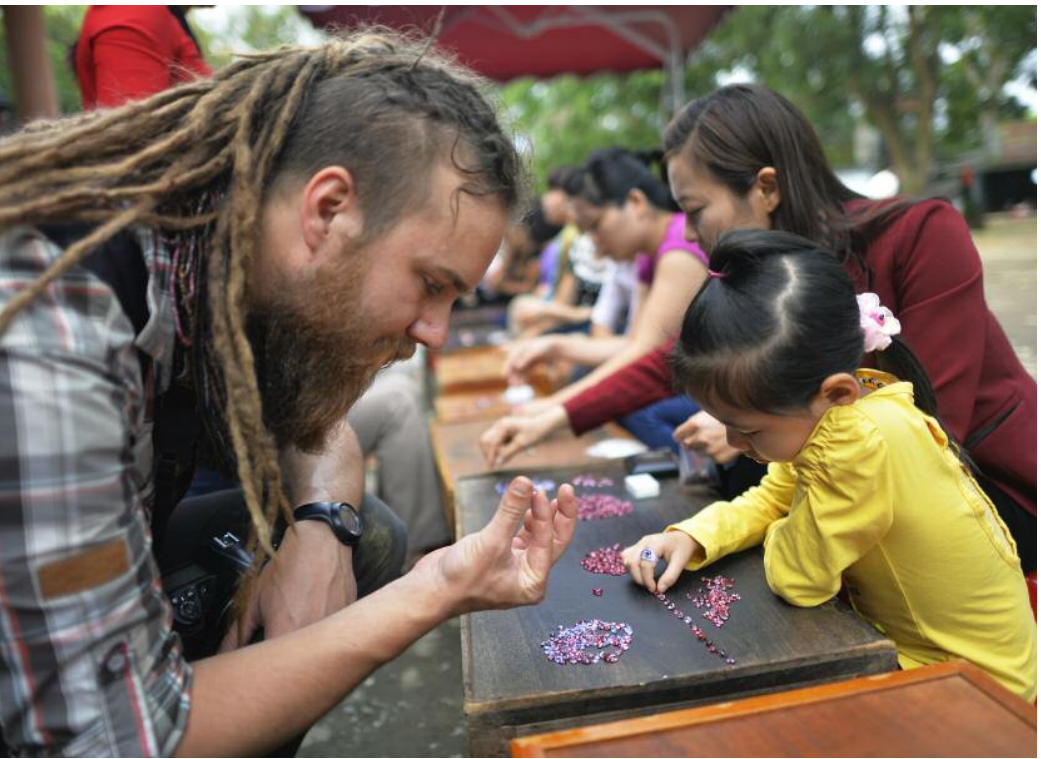

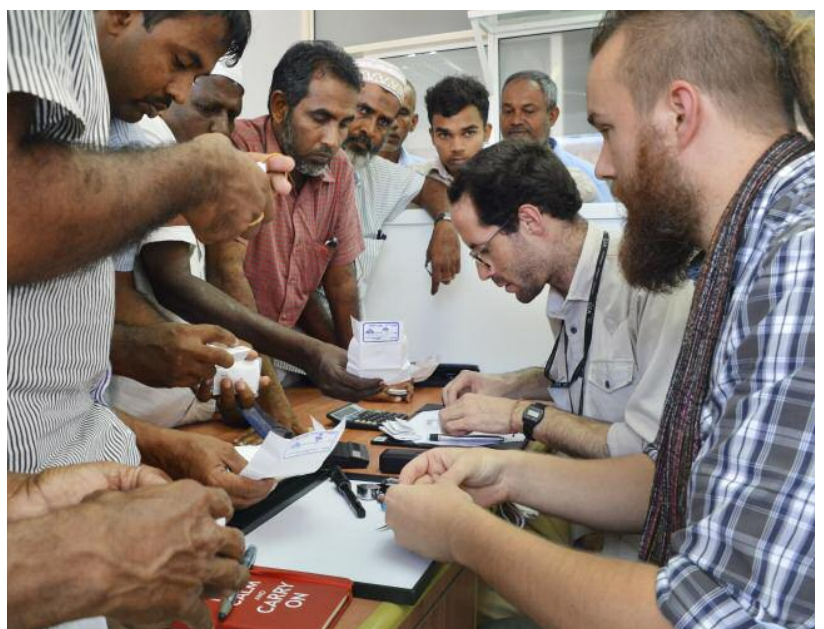

Figure 8. F-type sampling: Inspecting Madagascar sapphires in an office in Beruwala, Sri Lanka. Photo by Vincent Pardieu.

terial from sources such as museum collections is also included in this category.

- Z-type samples are those that have no origin information. These can still be useful in some cases. For example, a recent study of the effect of heating on basalt-related sapphires did not require stones from specific locations. So we decided to spare the samples with known origin and use Z-type samples. Stones are also categorized as Z-type when the initial collection data are suspected to be inaccurate (everyone who buys in the field makes mistakes). On one occasion, we found a synthetic and two heat-treated stones in a C-type parcel of 90 stones. Because of this discovery, the whole parcel lost credibility and was reclassified as Z-type.

Material gathered by all of these means is valuable for research, as long as the collection circumstances are known. That is why GIA also includes other information with its samples. Every sample has GPS coordinates from the acquisition site attached to it, and the mine coordinates are added when available. Other information includes species and variety, sample price, seller identity, locality details, and the possibility of treatment (again, see figure 2). If this information is not available, valuable data are missing. Careful and precise logging of this information is critical, especially if the collection will have multiple users over time. 


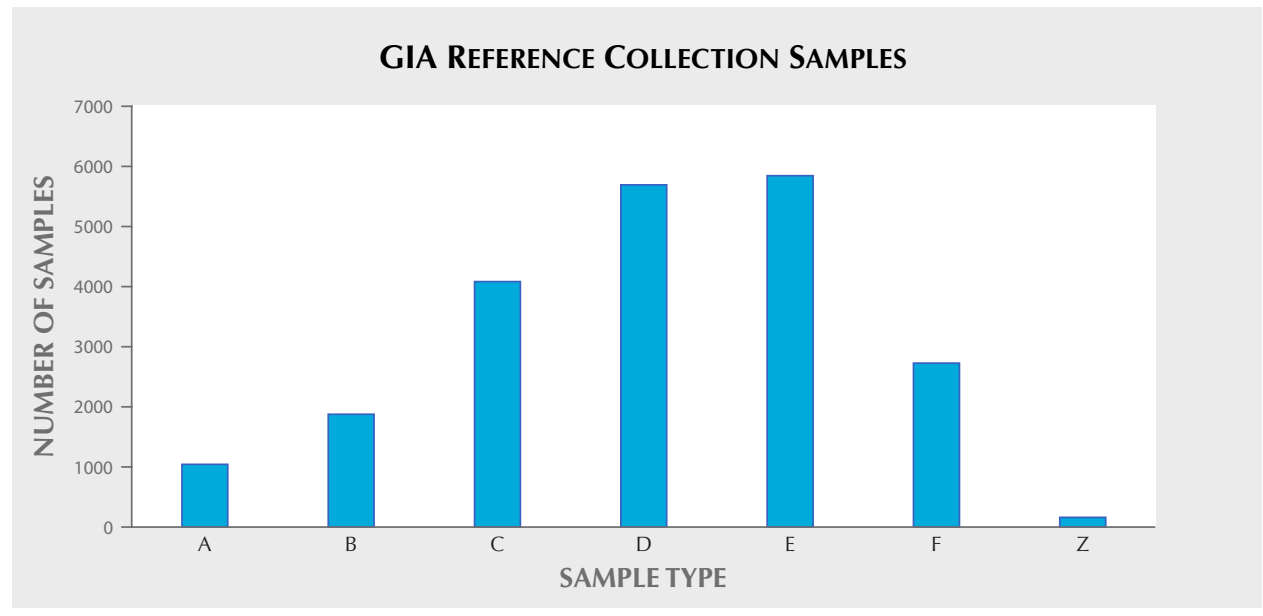

Figure 9. The number of samples of each type in GIA's reference collection.

\section{GIA'S RESEARCH COLLECTION IN THE REAL WORLD}

In an ideal world, GIA's collection would consist of only A-type stones mined by GIA field gemologists, but unfortunately gem-quality material found in these conditions is very rare. To best support origin determination services, we still collect samples in all other circumstances (figure 9). This is a common practice when new deposits are discovered. First the material becomes available in an international market, where some samples (F-type) are obtained by GIA for initial analysis. Visiting a new mining location usually involves substantial preparation and planning, so a few months could pass before sample collection at the mine (A- to C-type) occurs. In the meantime, stones from these new mines could become available in the market and be submitted to GIA's laboratories.

This is why we rely heavily on stones with different classification codes. Even if their reliability is lower than A-type, they allow us to conduct preliminary research, to later be supported with data from more reliable samples.

Field gemology supports the research on geographic origin at GIA laboratories. Traditionally, origin determination was only requested for the three most important colored stones: ruby, sapphire, and emerald. These have been the focus of the field gemology program's sampling expeditions for the first decade. Because gem corundum is also the subject of many treatment experiments, a significant part of the collection consists of ruby, sapphire, and fancy sapphire (figure 10).

With increasing demand for geographic origin determination for a wider variety of gemstones, GIA's colored stone reference collection needs to be diversified. In the last two years, significant efforts have been made to collect alexandrite, cuprian tourmaline, and other gemstones. Many of the samples used in origin determination research of cuprian tourma-

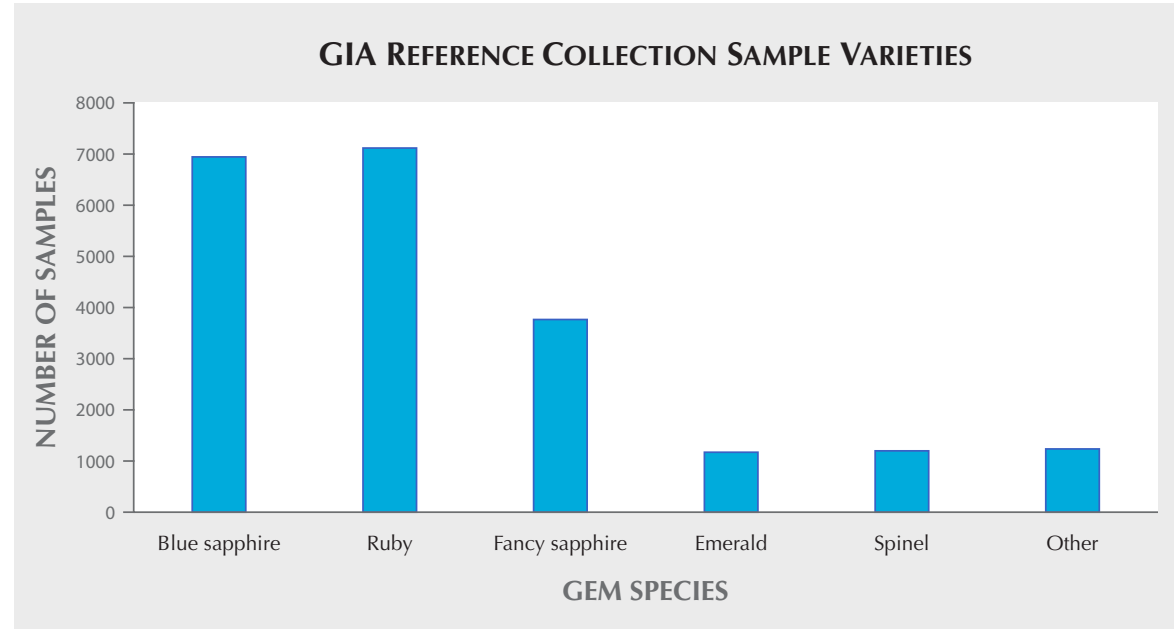

GIA FieLd Gemology
Figure 10. The number of samples of each gemstone variety in GIA's reference collection. Fancy sapphire includes yellow, green, purple, and colorchange corundum as well as pink sapphires, which are used to complement ruby studies. The others are mainly rock samples but include alexandrite, tourmaline (cuprian and non-cuprian), garnet, tanzanite, and other gem minerals. 


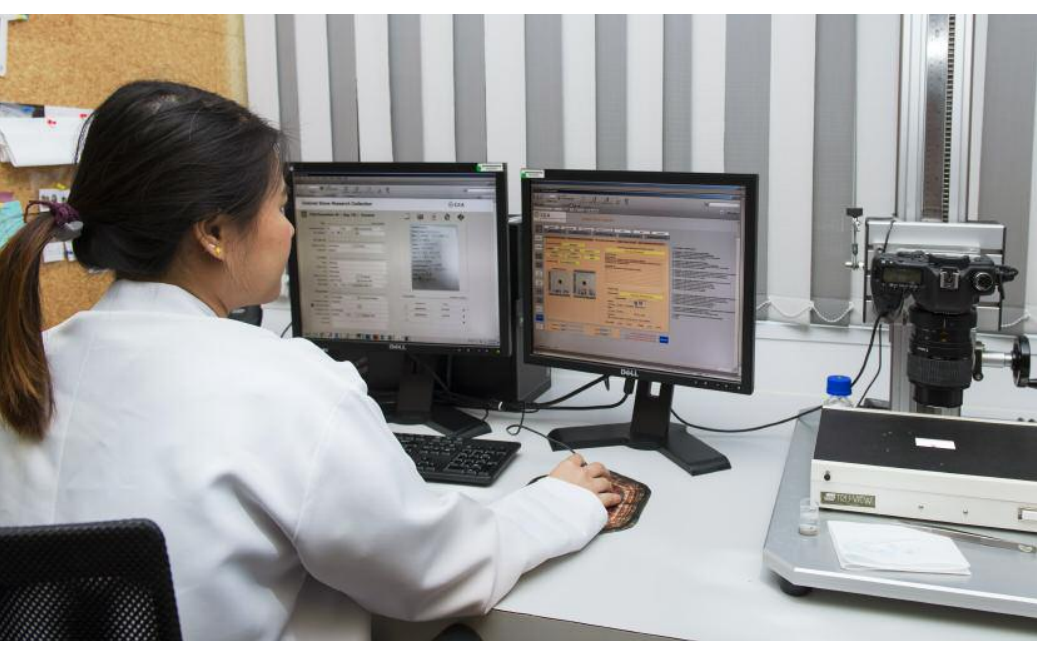

Figure 11. Stone librarians enter field data and colorcalibrated photos into the digital database, which is accessible by gemologists in all GIA laboratories. Photo by Nuttapol Kitdee.

line and alexandrite are still acquired in the trade (Eand F-type), but GIA is actively working on visiting the mining sites and collecting samples there.

Sample collecting is only the first step in the life of a research sample. Once the material is acquired by GIA field gemologists and shipped back to the lab, it needs to be added to a database that provides an overview for the entire collection. A GIA stone librarian enters all the available data in a digital database that is accessible to GIA colored stone identification staff around the world (figure 11). The data are accompanied by a color-calibrated photo of the rough piece. Documenting all pieces in exactly the same lighting conditions allows a preliminary color comparison of different samples based on digital images. All of the accompanying field data is printed on a labeled cassette in which the stone is stored in the physical library.

The majority of stones collected in the field are rough pebbles. This means they have some form of skin and are not fully transparent and thus need to be prepared for analytical procedures. In order to observe inclusions and obtain high-quality spectroscopic data, it is critical that windows with an excellent polish be faceted on the stones. This is done with traditional lapidary techniques using precision cutting machines to guarantee large, flat surfaces (figure 12).

However, for research samples, especially when looking at spectroscopy, orientation of the windows/facets is very important. The majority of stones in the research collection are dichroic (corundum and beryl), which means their optical properties

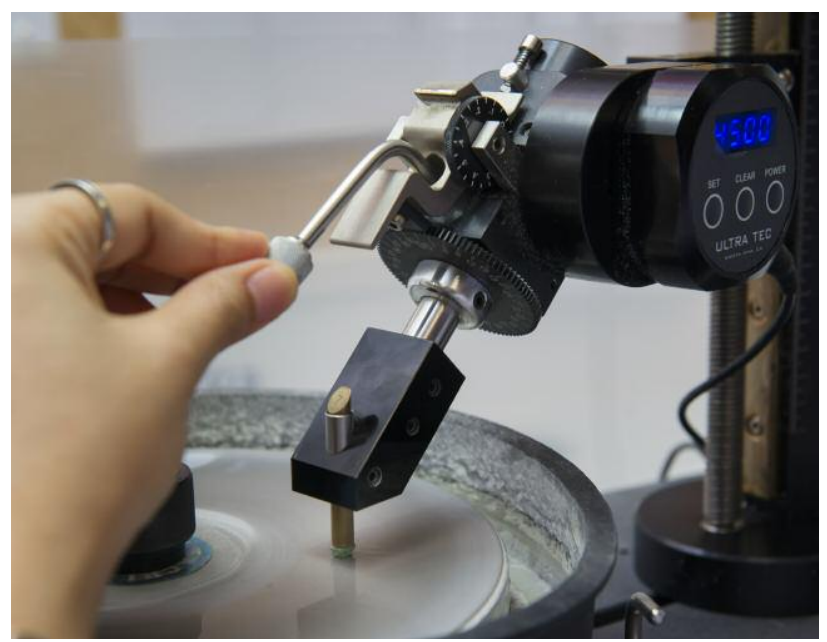

Figure 12. Before a sample can be analyzed, it must be prepared. This preparation involves polishing large, flat windows on the stone with a minimum of polish lines. This can be achieved using precision cutting machines. Photo by Nuttapol Kitdee.

vary depending on the direction in which they are observed. To make sure we compare every sample in the proper direction, for samples chosen for spectroscopy we align the c-axis parallel or perpendicular to the polished windows. By using a custom-made instrument that allows us to locate the c-axis position within one degree (Thomas et al., 2014), we know that all spectra collected on our stones are comparable (figure 13). For inclusion observation it is also important to have varying window orientations since some two-dimensional internal features (e.g., needles and platelets) are associated with the crystal structure and thus nearly invisible from certain angles. A variety of orientations allows more possibilities to explore the inclusion scene in a gem.

Polishing windows also removes the stone's outer layer, which might be encrusted with mud, host rock, or other material. By analyzing the trace element chemistry on a freshly polished surface, contamination by surface features such as iron staining is avoided. It also allows us to target specific zones within the crystal more precisely. This is often the case with blue sapphire, where color zoning is extremely common and the internal trace element concentration can vary considerably.

The majority of research stones go through the same analytical procedures as gems submitted by clients. Documenting inclusions with photomicrography is the first step. If the stone is extremely clean, it can be used for color analysis. In these high-quality wafers, there are no discernible internal features that can disturb light traveling through them. This allows 


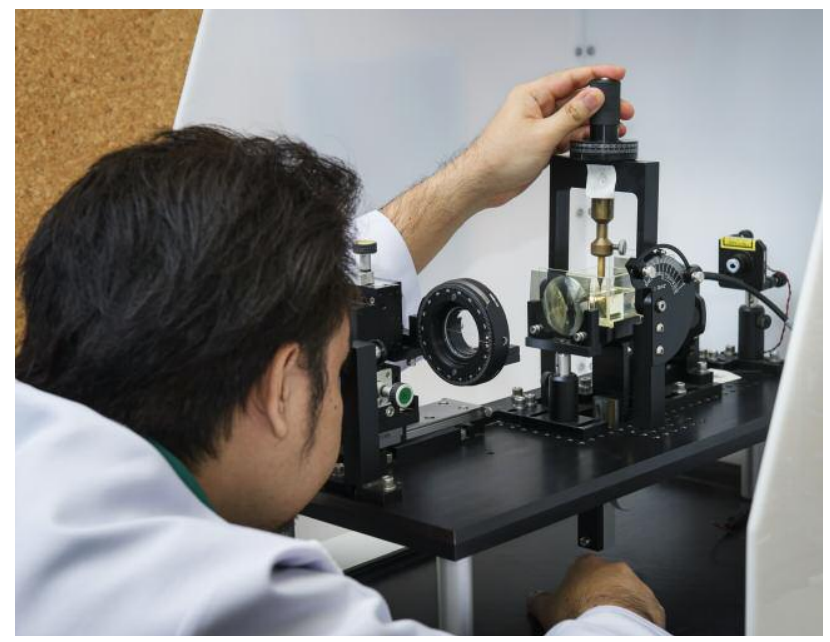

Figure 13. Selected samples with very high clarity are often aligned to the c-axis using this custom-built instrument. Aligning all samples allows for a precise characterization of the wavelength absorption in certain directions and guarantees that different samples can be compared. Photo by Nuttapol Kitdee.

for precise analysis of the absorption spectrum in the ultraviolet, visible, and near-infrared light range, which is used to identify the causes of color in the material.

FTIR spectroscopy and trace element chemistry data are also collected. All of the data associated with a research sample, ranging from refractive index to trace element concentrations, are available to GIA gemologists worldwide through the digital database.

To explore new techniques, a portion of the research samples are also used for analysis that is not routinely conducted on colored stones in gemological laboratories. In recent years, stones have been used for destructive analysis to measure rare earth element concentrations and isotope ratios as well as studies on various luminescence techniques.

Ultimately, the samples are stored in the GIA colored stone reference collection in Bangkok (figure 14). This library consists of four subsections:

- Premium gems: These stones are readily usable for routine gemological analysis. These samples are sufficiently large and free of fractures, combined with a desirable color.

- Treated gems: The GIA colored stone reference collection includes numerous stones that are known to have been subjected to treatment. Some were acquired as treated, but the majority are the result of GIA's internal treatment experiments, focused mainly on heating of rubies and blue sapphires.

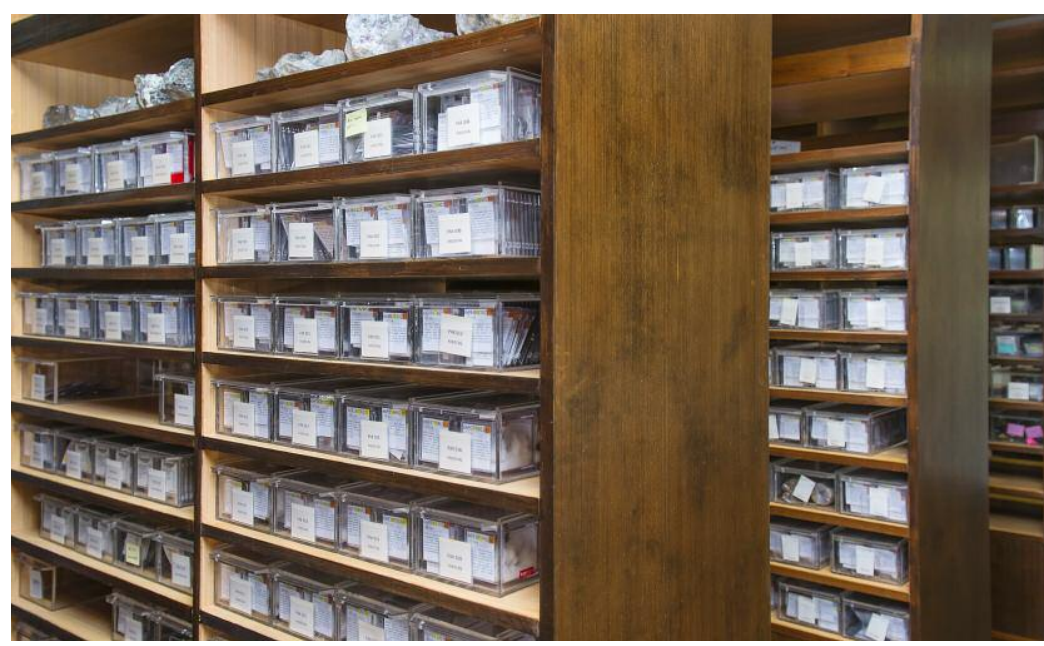

Figure 14. GIA's colored stone reference collection is managed by the Bangkok lab, where the majority of samples are kept in the field gemology department. Photo by Nuttapol Kitdee.

- Matrix material: While visiting mines, GIA field gemologists document the host rock and collect associated minerals. This section of the collection, though currently underutilized, offers significant potential for future studies on the geology of gem deposits.

- Basic gems: Much of the material that is collected is not readily usable for routine gemological analysis due to lower quality (e.g., abundant fractures and small sizes). These samples are still valuable for studies that require destructive techniques or treatment procedures. Gem species other than the ones for which GIA offers origin determination are also included in this section.

Apart from the main library in Bangkok, there are satellite collections of most of the major gemstones in GIA's colored stone laboratories in Carlsbad, Hong Kong, New York, and Tokyo.

\section{THE EVOLUTION OF GEMSTONE DEPOSITS}

Active sources of gemstones are constantly shifting. The life of a gemstone deposit is often highly erratic and unpredictable. Some deposits, such as Ratnapura in Sri Lanka, have steadily produced high-quality material for centuries, while others have existed for only brief periods. One of the best examples is Winza, Tanzania, which produced fine rubies beginning in 2007 but was almost completely abandoned by 2010. Although deposits are routinely depleted, the material mined from them has the potential to circulate in the trade for generations. 


\section{Box A: Survival OF the Fittest}

Figure A-1 shows the shift of ruby mining areas on the East African mainland over the past century. The earliest ruby discovery in East Africa was near Longido, Tanzania, where ruby was found around the time of World War I. This hard-rock primary deposit is famous for specimens of ruby-in-zoisite. Mining these gemstones requires blasting and deep tunneling, making it a very expensive affair. While the material's color is good, its clarity is lacking, with most being opaque and of carving quality (Dirlam et al., 1992).

In the 1970s, ruby was discovered in the Mangare area in Kenya by John Saul. The gems are found in a primary deposit, but the ruby-hosting rock is quite weathered in the upper levels, making it fairly easy to mine. The color of this ruby was considered highly desirable, and the name "John Saul color" is sometimes used as a trade name for it. The material often lacks clarity, and the majority are cut into translucent cabochons. Most of it requires heat treatment to improve the clarity (Bridges, 1982).

In the following decades, rubies were discovered at several places in central Tanzania. However, none of those had the volume or quality to threaten Mangare's position as supreme producer on the African continent.

In 2007, fine rubies were discovered in a primary and nearby secondary deposit at Winza, Tanzania. The finest material had excellent clarity and fabulous color, but the lower-grade material could not be optimized by treatment, rendering much of the production useless as gemstones (Schwarz et al., 2008). Although there was initial optimism, the deposit was quickly abandoned. The majority of miners and buyers moved south across the border to Mozambique.

In 2009, facet-grade ruby was discovered near Montepuez, Mozambique. This material quickly became available in large volumes, various sizes, and a range of color intensities. Additionally, the material reacts well to treatments to optimize both color and clarity /Vertriest and Saeseaw, 2019). The wide availability of this material has had a dramatic impact on other ruby mining areas, which have been completely overshadowed by the giant deposit in Montepuez.

In 2017, many unlicensed buyers were expelled from Mozambique. These buyers, an important link in the supply chain, searched elsewhere in East Africa for a ruby source that met their needs. Around the same time, facet-grade rubies were discovered in Longido, the mine originally known for its carving-grade material. This new

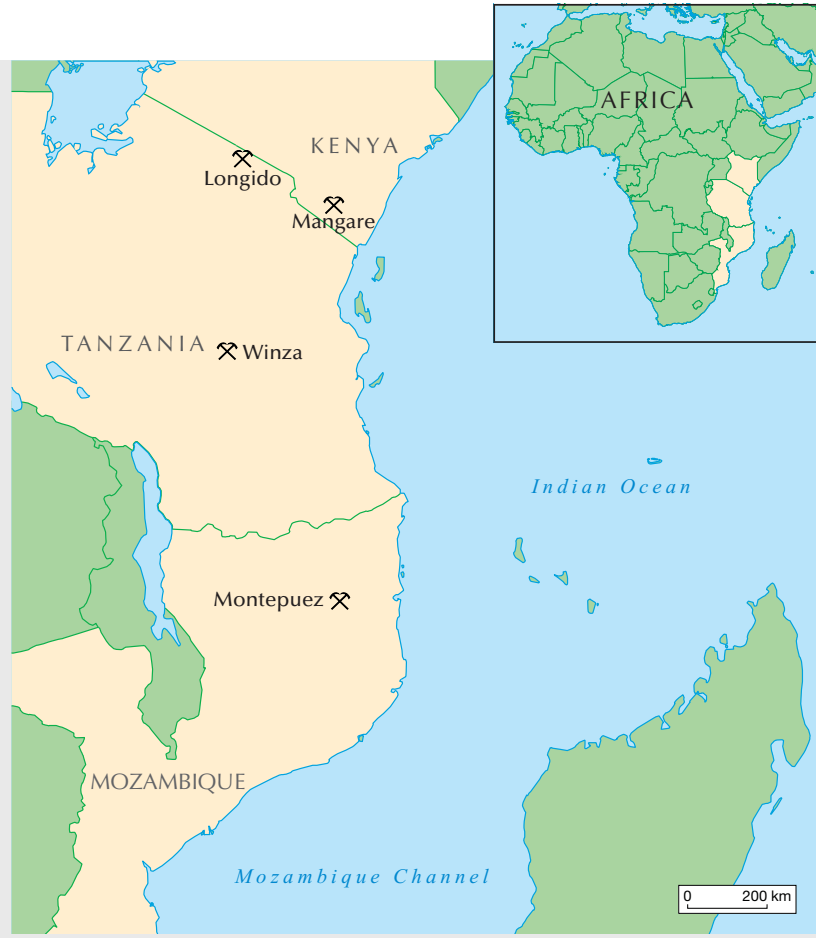

Figure A-1. This map shows the locations of the mines that dominated ruby production on the East African mainland in the last century. The Longido and Mangare mines were famous for their fine-color but low-clarity stones. Several deposits produced smaller volumes of goods but were never competitors. Winza generated some excitement by producing fine faceted rubies, but its life span was rather short. The Montepuez deposit in Mozambique has overshadowed all the other deposits, but internal turmoil has forced traders to revisit old deposits such as Longido, where new types of ruby are being mined.

material from an old mine has highly desirable colors but is only available in smaller sizes (Pardieu, 2019). While the renewed interest has not made it a serious competitor to Montepuez in Mozambique, it has certainly revived the ruby trade in northern Tanzania and provided rough ruby buyers with an alternative source for melee and small calibrated stones.

While the deposits might have unstable histories, the gems themselves are durable and here to stay, whether a deposit produces for centuries or only a few months. A complete and reliable reference collection contains stones from all of these deposits.
Understanding the evolution of a gemstone deposit is critical for a field gemologist. GIA's field gemologists aim to stay aware of new developments in sourcing and treatments because they can have a sudden impact on the global gem trade. The field gemology program allows GIA to adapt its procedures as quickly as possible to account for emerging sources and treatments. 


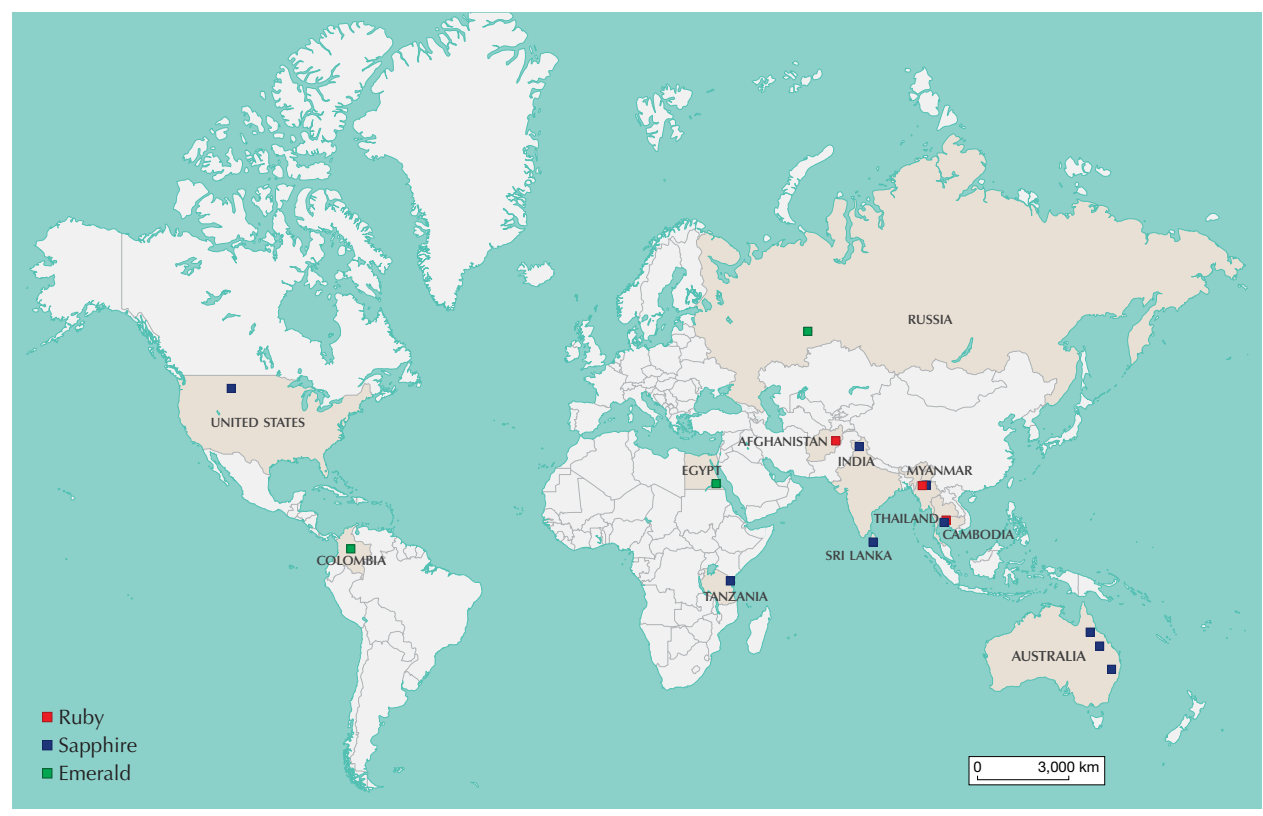

Figure 15. Map of classical ruby, sapphire, and emerald deposits that were highly influential before the rise of the modern gem trade.

The Life of a Gemstone Deposit. Many gemstone deposits have been established for several decades or even centuries, so their early histories are often unknown. In the last decades, many new sources have emerged, and GIA has been fortunate to witness their development.

Most new deposits share a similar story: It starts with an accidental discovery, usually by people who travel extensively through unexplored lands, such as gold panners, lumberjacks, or nomadic tribes. They find a beautiful rock but are unaware of its value. Eventually, someone discovers the value of these crystals. This often triggers a rush of small-scale miners, who begin a frenzied search for more of the material or anything that looks like it.

A nearby group of buyers is critical to sustain a young deposit. Production will halt quickly if no buyers are on hand to trade the stones for cash. Often these are local traders, but sometimes international buyers are also present from the start. Regardless, this all takes place close to the mines. The local buyers will provide this material to the global market, where international gem traders and wholesalers become aware of it. Sometimes this process takes a few years, but it could happen in just a few weeks. In recent years, mobile phones and social media have become popular in mining areas. This has increased the speed of information and changed the way it spreads through the trade, even though the development of a deposit is essentially still the same.

The process of gem discovery is not always constant - there are many external forces involved. A gem mining rush in a remote area is often closely related to local socioeconomic challenges, some of which can severely disrupt mining. In many cases these finds are in tropical countries with strong seasonal changes that prevent mining part of the year, which can limit the mining season to a couple of months. In some cases, mining does not resume when the weather clears. A range of situations can cause newly discovered mining areas to be abandoned.

The most serious threat to the development of gemstone deposits is probably the emergence of other deposits. Here the Darwinian principle "survival of the fittest" applies. A new deposit that is easier to work, faster to reach, delivers higher volumes, or produces more marketable stones that react better to treatments will cause others to be ruthlessly abandoned by miners and/or local buyers (see box A).

Keeping track of these developments is a critical aspect of the field gemologist's job, since deposits can show up and disappear in the most unexpected ways. This might present only a brief window to collect reliable samples, but one that is enough to produce a huge volume of gems that will influence the market and be submitted to labs for decades to come.

Overview of Important Gemstone Deposits. The use of gems in early civilizations and empires is well known: Cleopatra's emeralds, Sri Lankan sapphires in Roman signet rings, Central Asian spinels and rubies in European royal treasuries, and Colombian emeralds in Indian Mughal jewelry. Such examples show that gems traveled the planet even in times 


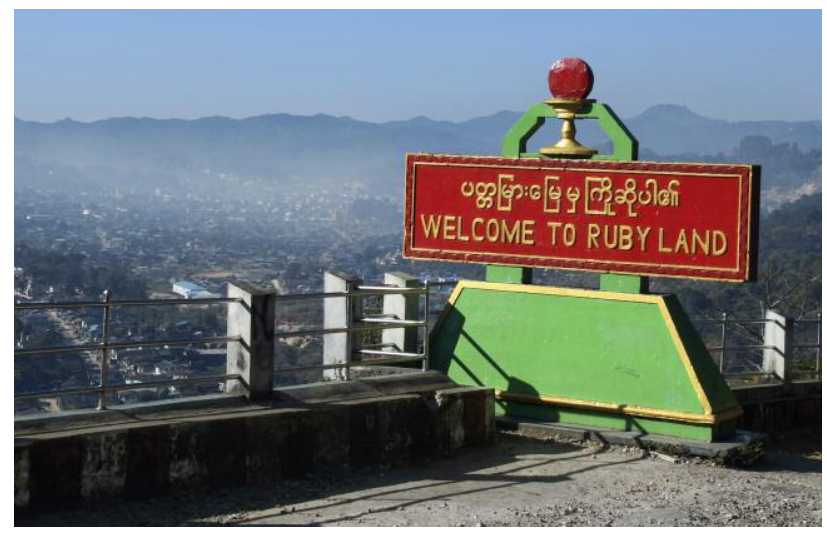

Figure 16. Mogok, Myanmar, is the most famous of all ruby sources. Its mining history stretches over centuries, and its close connection with the red gemstone is the reason for its nickname "Ruby Land." Photo by Wim Vertriest.

when the concept of global mobility was unheard of. Back then, a single locality could have an outsized impact on the international trade.

The following is a brief overview of deposits that can be considered classical (figure 15). Gems from these areas heavily influenced the world trade before the rise of modern gemology and gem trading, roughly during the 1960s and 1970s. In the case of gem sources, classical does not necessarily mean exhausted. Many of these locations are still relevant gem mining regions. Most of this information is dis- tilled from Ruby et Sapphire: A Gemologist's Guide (Hughes et al., 2017), supplemented with GIA's field gemology observations during expeditions in the last decade.

Ruby

- Mogok, Myanmar, is the world's most revered ruby locality. Ruby is an integral part of the local culture, and the Mogok Valley is sometimes referred to as "Ruby Land" (figure 16).

- Afghanistan's ruby mines delivered many of the rubies and pink sapphires for the treasuries of Indian rulers. For centuries, artisanal miners have extracted rubies from these hard rock mines in the marble hills just east of Kabul, although production is very limited nowadays.

- The border area between Thailand and Cambodia began supplying rubies around 200 years ago and peaked in the 1970s and '80s. By the 2000s, production had virtually halted. Rubies have been found here in alluvial deposits related to the weathering of corundumbearing alkali basalts.

\section{Metamorphic Sapphire}

- The most famous historical sapphire source is Sri Lanka, formerly Ceylon, which still produces large volumes of high-quality

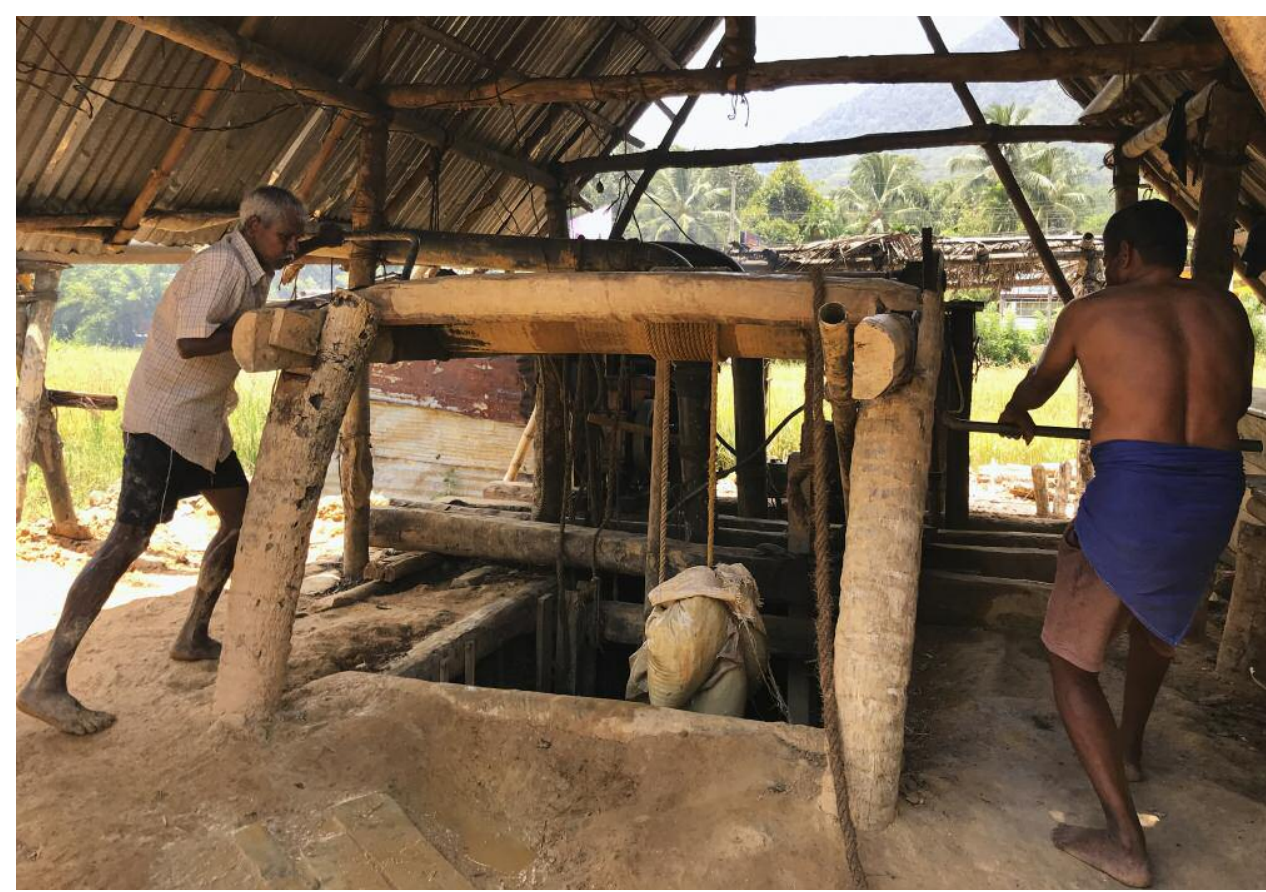

Figure 17. Sapphire mining in Sri Lanka is still dominated by artisanal, man-powered techniques to this day. They have not changed in centuries, and largescale mining is limited. Photo by Wim Vertriest. 


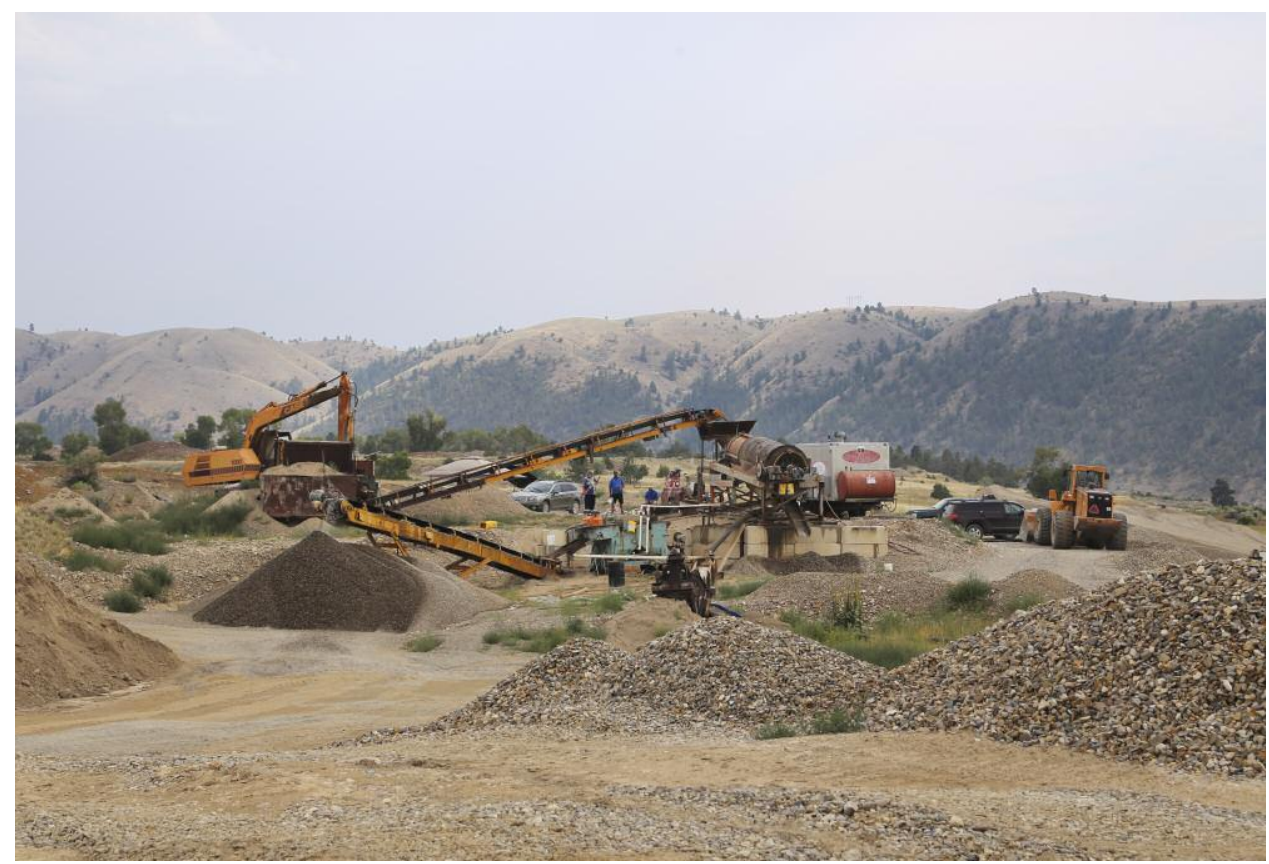

Figure 18. Sapphires are still being mined in the rugged mountains of Montana by the Spokane Bar Sapphire Mine. A handful of companies run mechanized and efficient mining operations to retrieve rough gems during the summer months. Photo by Nathan Renfro.

stones (figure 17). New discoveries are still being made-for example, a large rush occurred in 2012 at a new deposit near Kataragama when a large concentration of high-value sapphires was found in an area not previously known to contain such quality material (Pardieu et al., 2012; Zoysa and Rahuman, 2012).

- Along with ruby, Mogok supplies a variety of high-quality gems, including fine blue sapphires and star sapphires. Some of these rough sapphires can reach enormous sizes, although these Burmese giants usually have limited clarity and unattractive color.

- The disputed region of Kashmir produced the world's most coveted sapphires for a brief time in the late 1800s. Even today, sapphires from the original discovery are perceived as legendary. Recent output from this area is of lower quality.

- The Umba Valley in Tanzania yielded a variety of sapphires, mainly fancy-color, from World War II until the mid-1970s. A few artisanal miners are still working in the Umba River.

\section{Igneous-Related Sapphire}

- Sapphires from Pailin, Cambodia, were discovered and reached their height around the time when Kashmir sapphires were at peak production. Pailin sapphire is very limited now and consists mainly of smaller sizes.
- Australia is estimated to be one of the largest sapphire mining nations by volume. The mines have produced for over 100 years, but output peaked in the 1960s and 1970s. During this period, Australia was the main source of blue sapphire for the international trade, with large mines and many foreign buyers operating there.

- Chanthaburi, Thailand, is known as a trading and treatment center, but it was once the center of a flourishing sapphire mining community. Several hills around the city are ancient basalt volcanoes that brought dark blue and fancy sapphires to the surface. The mines near Chanthaburi are well known for their fine black star sapphires and dark yellow "Mekong whiskey" stones.

- In the United States, Montana saw millions of carats of sapphire mined from the late 1800 s to early 1900 s, mostly for use in the watch industry but with many entering the gem market (figure 18). The finest blue sapphires from Montana were produced in the Yogo Gulch deposit (Renfro et al., 2018). In recent years, some of the state's mining operations have been revived (Hsu et al., 2017).

\section{Emerald}

- Colombia is the world's most prized locality for emeralds because of their long history and fine quality. Pre-Columbian civilizations al- 


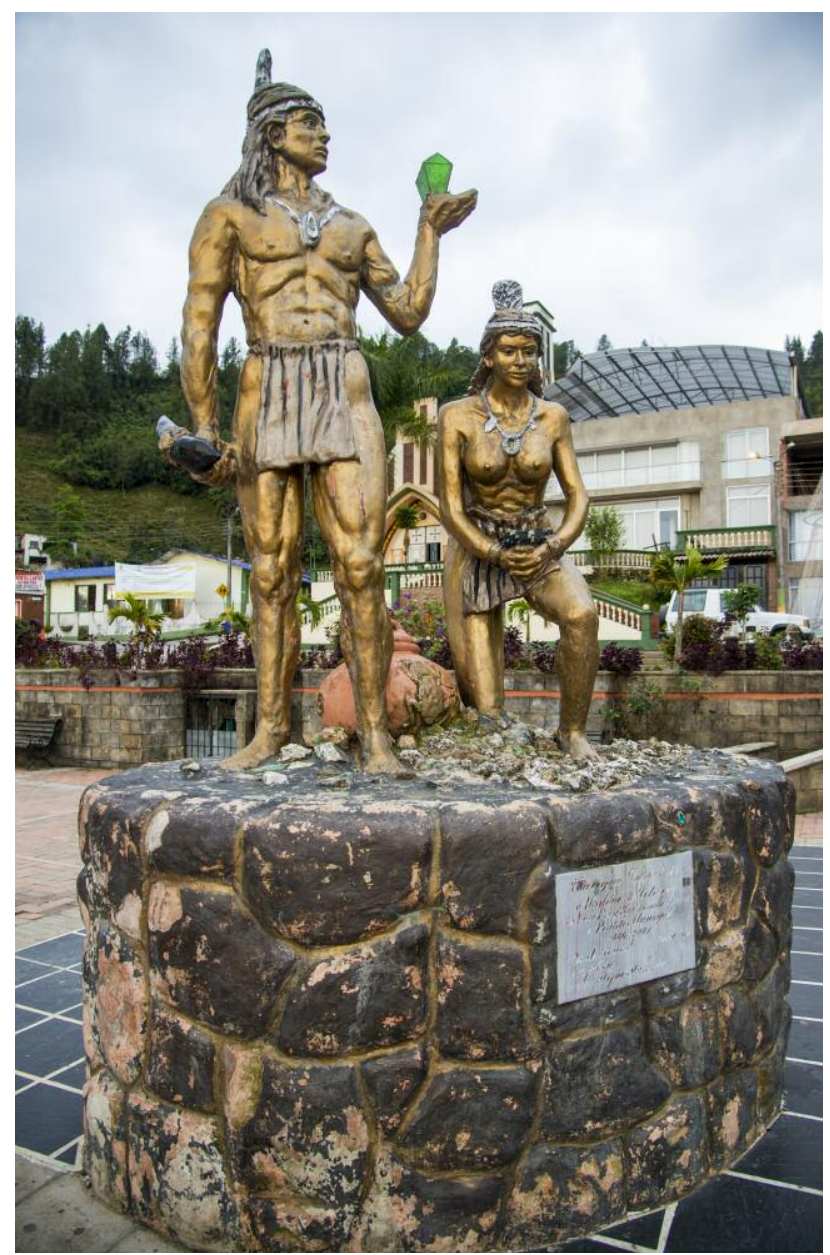

Figure 19. The statue on Chivor's main square, in the heart of the Colombian emerald mining region, serves as a reminder of the gem's long history there. Emeralds have been important in the region for centuries and were already greatly revered by pre-Columbian civilizations. Photo by Robert Weldon/GIA.

ready held the gem in high esteem (figure 19). After their discovery by Spanish conquistadors, emeralds were brought to Europe and the rest of the world where they were highly treasured in the European royal courts as well as the Mughal palaces of India.

- Mines in southern Egypt are the presumed source of the Egyptian and Roman empires' emeralds. These mines were abandoned after their peak, and when emeralds from the New World started entering the old continent in the 1500s, the Egyptian mines were all but forgotten. In the 1800s they were rediscovered by French colonial explorers, who tried unsuccessfully to reopen them (Jennings et al., 1993; Johnson and Koivula, 1997).
- Russian emeralds have been mined near the town of Malysheva in the Ural Mountains since the 1830s (Schmetzer et al., 1991). For much of the twentieth century, the mine's emphasis was on beryllium metal for strategic and industrial applications. In 2018, the new management significantly increased production of emeralds, parallel to the mining of other minerals for beryllium extraction (Burlakov and Burlakov, 2018).

\section{Red and Pink Spinel}

- For centuries, the Central Asian region of Badakhshan, straddling the borders of Tajikistan, Afghanistan, and China, has produced magnificent spinels. They were often mistaken for rubies in medieval times and were well known by the term "Balas ruby." One of the most famous colored stones in the world, the Black Prince's "Ruby" in the United Kingdom's Imperial State Crown, is actually a Badakhshan spinel. The Kuh-i-Lal area in Tajikistan is considered the most important source of fine red spinel in the region (Pardieu and Farkhodova, 2019).

- Although Myanmar holds incredible volumes of spinel in the Mogok and Namya areas, it has always been in the shadow of the ruby and sapphire that are also found there. In the last 20 years, the mines in Man Sin (Mogok) and Namya (Hpakant) have become famous for the so-called Jedi spinel, characterized by an intense color and fluorescence (Pardieu, 2014).

\section{Alexandrite}

- Alexandrite was first documented in the Ural Mountains of Russia. The greens and reds of this newly discovered color-change chrysoberyl variety matched the Russian imperial colors, and thus the stone was named after the future Czar Alexander II. Its occurrence is closely associated with emerald. Fine Russian alexandrite is still considered the standard by which all color-change gems are measured (Schmetzer, 2010).

In recent decades, many new sources have come into the gem trade (see figure 20). There is no strict guideline for when a modern source becomes classical. As a rule of thumb, modern sources are considered to be deposits that began producing after the rise of modern gemology and whose discoveries have been well documented. 


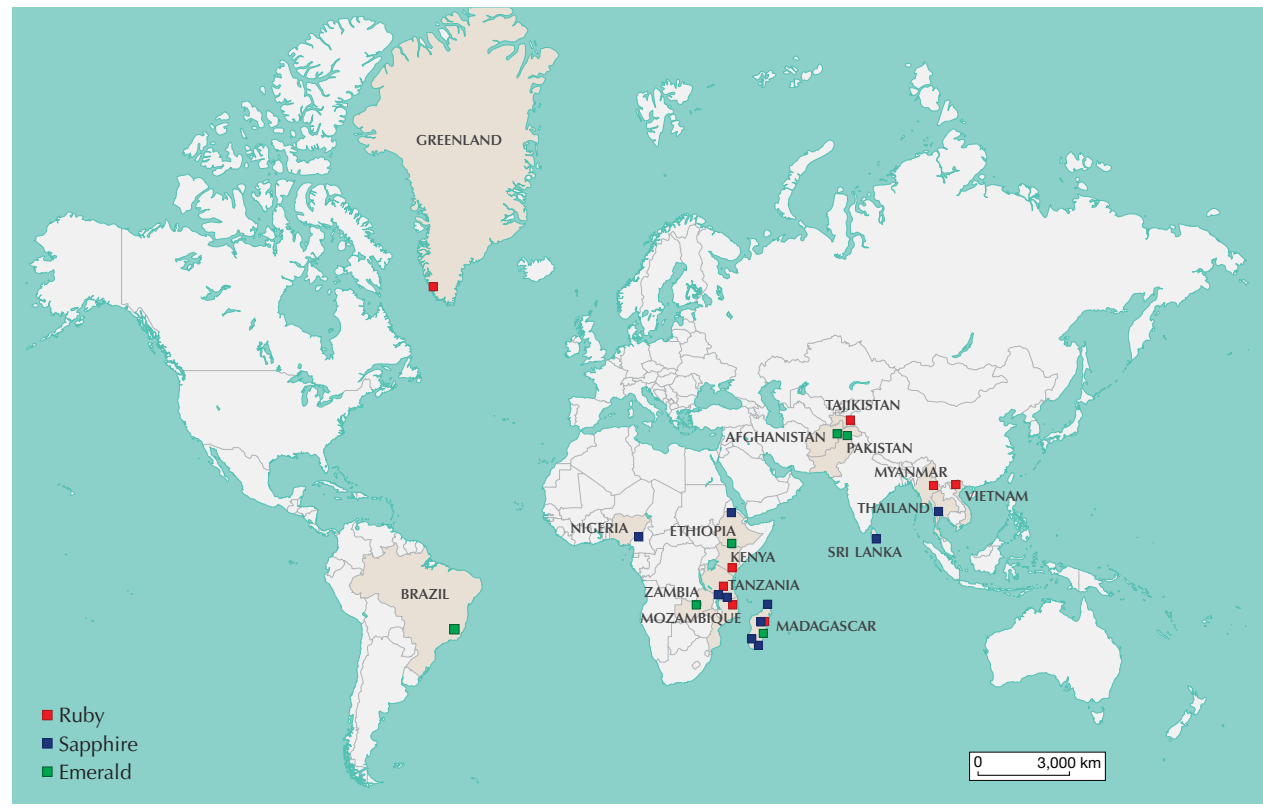

Figure 20. Map of ruby, sapphire, and emerald deposits that have emerged in recent decades.

The vast majority of modern deposits are in East Africa, a gemstone-rich area that did not historically have a strong cultural connection to gemstones, unlike the Asian countries of Sri Lanka or Myanmar. The increasing knowledge about gemstones and international travel by dealers provided an opportunity for these deposits to be discovered and establish a presence on the world market.

\section{Ruby}

- In 1973, John Saul and his team discovered ruby in the Mangare area of Kenya. This material has fine color but requires heat treatment to heal the abundant fractures. Most of the gems from this deposit were cut as cabochons. Initially production was considerable, but it has diminished greatly in the last 20 years (Bridges, 1982; Emmett, 1999).

- During the late Soviet period (1979), geologists discovered the Snezhnoe ("Snowy") ruby mine near Murghab, Tajikistan, at an altitude of 4,000 meters. Artisanal mining is restricted to the summer months, when small crews of workers break rubies out of the hard marbles. Tajik rubies are typically pinkish to purplish red but have strong fluorescence (Smith, 1998).

- In 1983, rubies were first reported near the village of An Phu in the Luc Yen District of Vietnam. In the following years, corundum was found in neighboring valleys, and in 1987 the first larger-scale operation began. These industrial operations were only profitable for a few years, and since the 1990s only artisanal miners have been able to work these deposits in the remote jungle mountains of northern Vietnam (Pardieu and Long, 2010; Trivier, 2018).

- Ruby in Mong Hsu, Myanmar, was discovered in the early 1990s. Many miners began working here and sold the material to Thai buyers across the border. Almost 100 percent of the material is heat treated to remove a dark blue core in the center of the crystals (Koivula et al., 1993; Peretti et al., 1995).

- In 2007, a Tanzanian farmer found some rubies in a river near his farm. A few months later, a massive gem rush occurred at the deposit now known as Winza. For a few short years, fabulous rubies emerged from these mines. Many have blue color zones, sometimes resulting in bicolor ruby-sapphires. They react poorly to treatment, rendering most of the low-grade material useless (Schwarz et al., 2008).

- The jungles of northeastern Madagascar have provided fine rubies for more than 20 years. However, production has not been steady, and most stones reach the market in waves due to rushes by artisanal miners. The main rushes took place at Vatomandry in the early 2000s (Schwarz and Schmetzer, 2001), Moramanga in 2004 (Hughes et al., 2006), Didy in 2012 (Pardieu and Rakotosaona, 2012), and Zahamena in 2014 (Pardieu et al., 2015). 


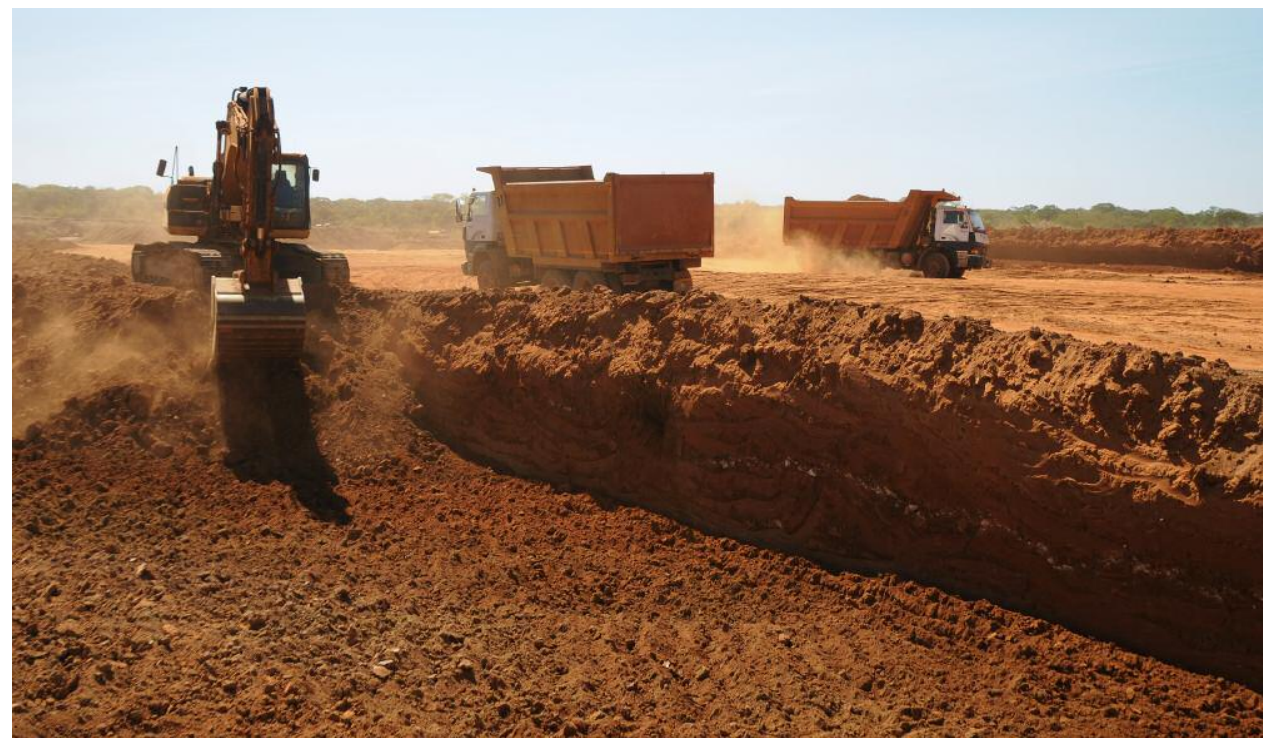

Figure 21. Currently the majority of Mozambican ruby is mined from mechanized, large-scale mining operations. Small-scale mining plays an important role, but less so year after year. Photo by Wim Vertriest.

- The most recent ruby discovery is the most important one. Since 2009, a variety of sizes and qualities have been mined near Montepuez, Mozambique (figure 21). In less than a decade, Mozambican rubies have conquered the trade and become widely available in every price range (Pardieu et al., 2009; Vertriest and Saeseaw, 2019).

- The newest large-scale ruby source is also the world's oldest deposit. Greenland's rubies and pink sapphires formed billions of years ago but have only become available to the public in the last several years. The rubies were already described by geologists in the 1960s. However, they were probably known by the local people long before, since the area is named Aappaluttoq, the Greenlandic word for "red."

\section{Metamorphic Sapphire}

- The southern Tanzanian deposits near Tunduru and Songea have produced sapphire and other gemstones such as garnets, alexandrites, and tourmalines since the early 1990s. Despite Tunduru's potential, it was never fully developed because of its remoteness and competition from other deposits. Sapphires from Songea span a full range of colors, but the majority were not seen as highly desirable due to strong modifying colors. Mining activity increased again in the early 2000s when the fancy sapphires reacted well to Be-diffusion treatment (Hughes and Pardieu, 2011).

- One of the first modern discoveries of highquality sapphire in Madagascar was in the southeastern part of the island. Andranondambo became famous for its blue sapphires, which were initially confused with Kashmir sapphires. Some attempts to set up large-scale mining operations were quickly abandoned (Kiefert et al., 1996; Schwarz et al., 1996). In 2016, a new find near the town of Vohitany brought fresh production to the market for a few months (Pardieu et al., 2016).

- One of the most important modern colored stone discoveries took place in another part of Madagascar, near the quiet town of Ilakaka in the southwest part of the island (figure 22). In 1996, large volumes of sapphire, fancy sapphire, and other gemstones were found in extensive riverbeds and associated paleochannels. The sapphires resemble Ceylon sapphires and react similarly to treatment, and thus the area attracts many buyers from Sri Lanka.

- Along with rubies, blue sapphires are found in the hilly jungles of northeastern Madagascar. Several rushes took place, bringing large volumes of sapphire to the market in a very short time. The first deposit that produced blue sapphire was Andrebabe in 2002, but it stayed largely under the radar. It was Didy that put this area of Madagascar on the sapphire map when large, high-quality material was found alongside the rubies during a rush in 2012 (Pardieu and Rakotosaona, 2012). In 2016, the Bemainty deposits produced padparadscha sapphires in addition to fine blue sapphires that were initially confused with 


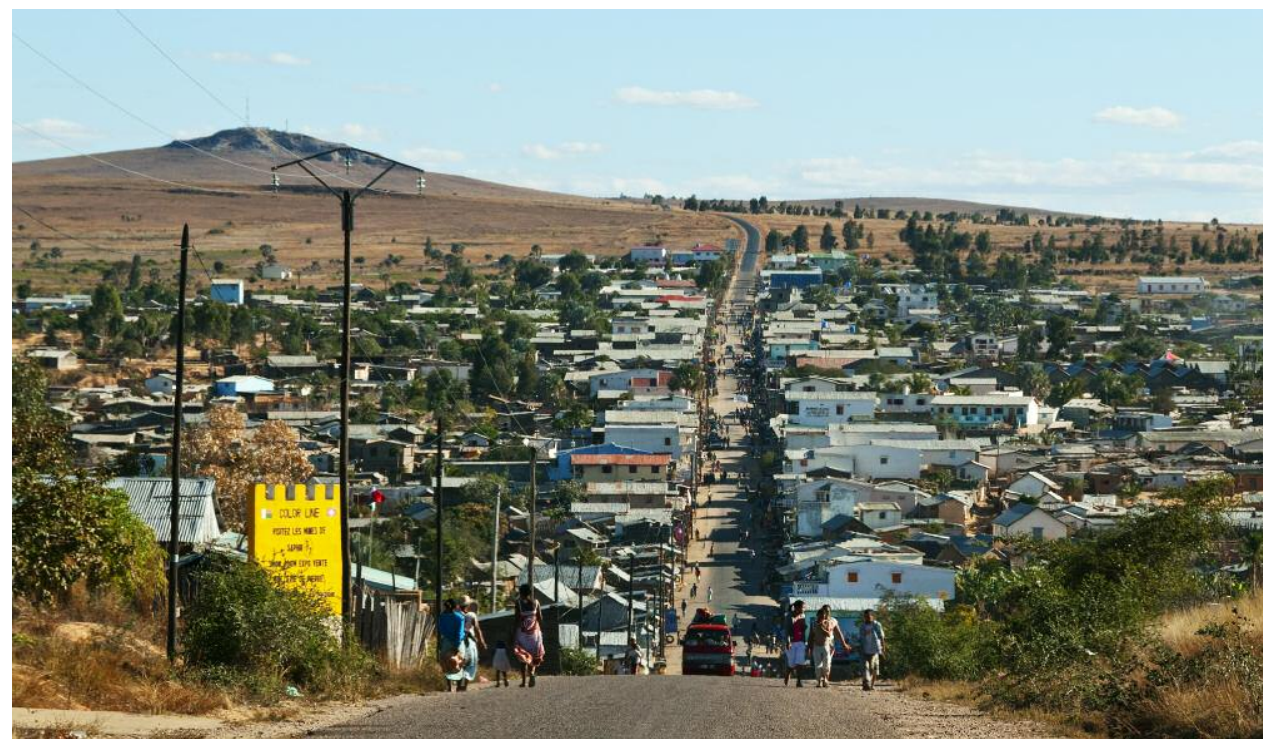

Figure 22. The quiet town of Ilakaka was transformed in the late 1990s by the discovery of huge sapphire deposits. It has quickly become one of the world's most important gem localities. Photo by Vincent Pardieu.

Kashmir sapphires. Laboratories made concerted efforts to correctly identify the origin of these stones, but it took several months to acquire reliable samples to study and make the distinction (Pardieu et al., 2017).

\section{Igneous-Related Sapphire}

- Kanchanaburi, Thailand, produced huge volumes of blue sapphire in the 1980s and early 1990s. Production continues but at much lower levels. Most of it consists of blue sapphire, but black spinel (pleonaste) is found as a byproduct (Gunawardene and Chawla, 1984; Koivula and Kammerling, 1990).
- Sapphire can also be found in the far north of Madagascar, in the area around Ambondromifehy, also known as Diego-Suarez. Since 1995, basalt-related sapphires have been recovered by artisanal miners. The blue stones are often heat treated to optimize their colors. Fine yellow and green stones are also found (Schwarz et al., 2000).

- The West African countries of Nigeria and Cameroon hold substantial reserves of sapphires. They were largely under the radar until the discovery of fine goods on the Mambilla Plateau in 2014 (Pardieu et al., 2014). High-quality sapphires are available in

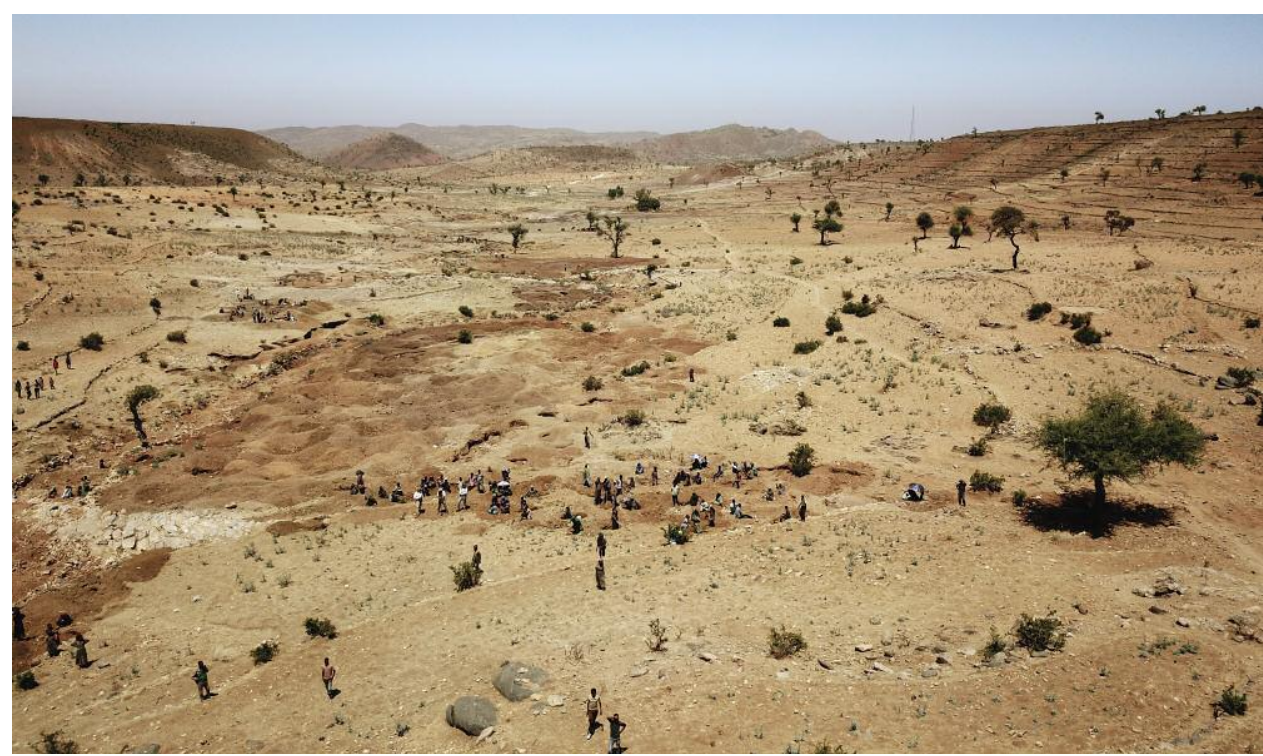

Figure 23. Ethiopian sapphire miners have been working in a remote part of the desert straddling the border with Eritrea since 2017. Photo by Wim Vertriest. 


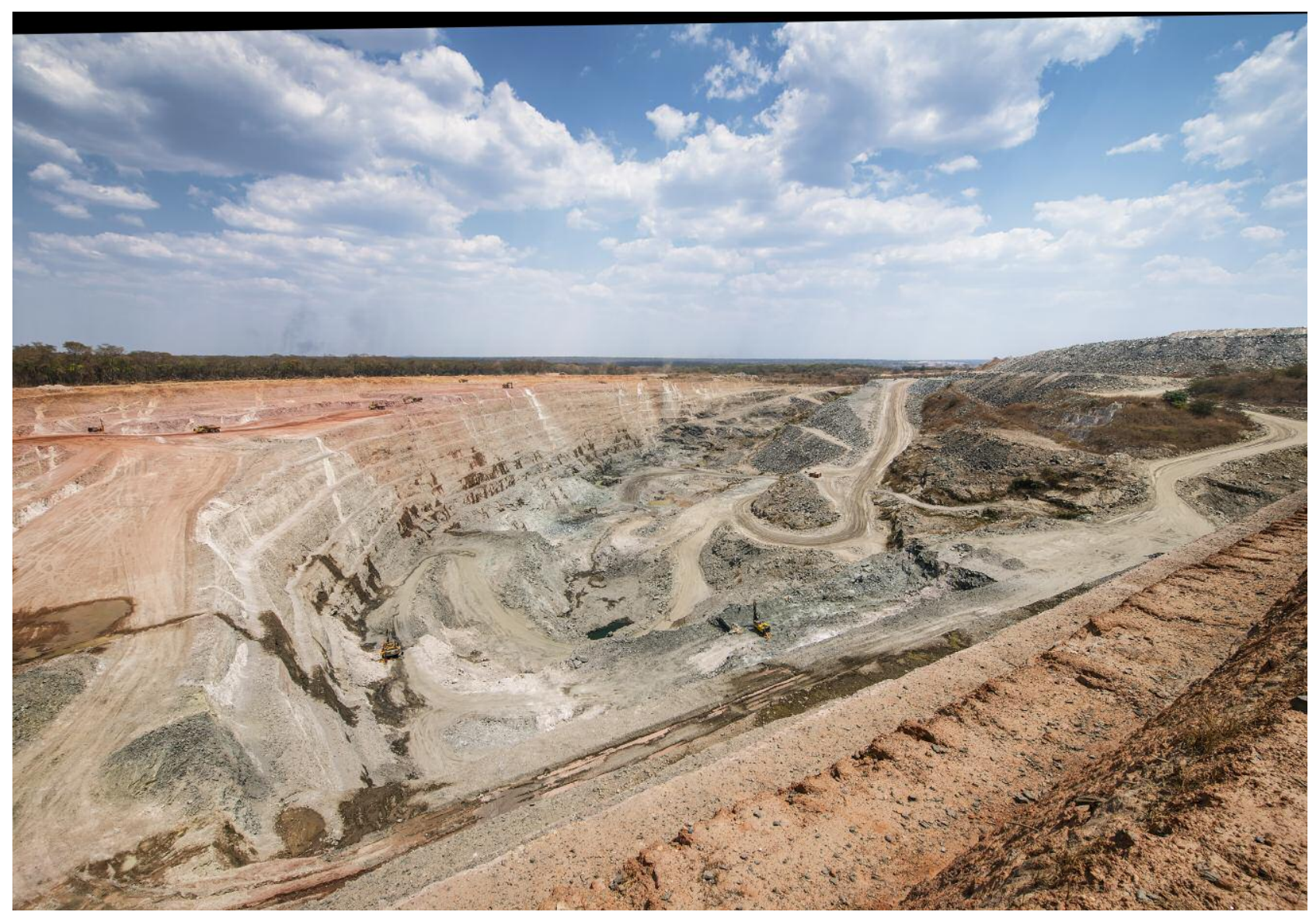

Figure 24. Zambian emeralds are mined from massive open pits that are among the largest colored stone operations in the world. Photo by Robert Weldon/GIA.

smaller volumes from other deposits in the eastern and northern parts of the country.

- The most recent discovery of good-quality basalt-related sapphire was in the northern Tigray Province of Ethiopia (2017) (figure 23). Artisanal miners work remote deposits in the desert straddling the border with Eritrea (Vertriest et al., 2017).

\section{Emerald}

- Central Asia has produced fine emeralds in the Panjshir (Afghanistan) and Swat (Pakistan) valleys since the 1970s and 1960s, respectively (Gübelin, 1982; Bowersox et al., 1991). Extraction methods are quite basic because the difficult working conditions prevent large-scale operations. Both areas produce fine quality, with the Panjshir Valley delivering well-formed crystals. The Swat Valley is mostly known for its smaller but deeply saturated clean emeralds that are in high demand in the watch industry.
- Zambian emeralds were first documented by colonial exploration geologists. It wasn't until the 1970s that gemstone mining began in the Kafubu area, which is still the world's leading emerald producer by volume. Several industrial operations are active, representing some of the largest colored stone mines in the world (figure 24) (Zwaan et al., 2005).

- Brazil has been a consistent supplier of emerald for the international market since its discovery in the 1970s. Capoeirana and Belmont in Minas Gerais State are the most important producers, with the latter being one of the world's largest and most advanced emerald mining operations. Mines in Bahia State and Santa Terezinha de Goiás are currently less important (Lucas, 2012).

- Emeralds were discovered in eastern Madagascar around the same time as in Brazil, but mining operations and production have remained limited. Nevertheless, some fine ma- 
terial has been produced in the past decades (Pardieu, 2018).

- The most recent emerald source is Ethiopia, where high-quality emeralds were discovered in 2016. The mines are in the southern part of the country, $70 \mathrm{~km}$ from the trading town of Shakiso. In its first years, Ethiopia made a strong impression on the market, but time will tell whether it can maintain its status as an important producer (Renfro et al., 2017).

\section{Paraíba Tourmaline}

- The original discovery of Paraíba tourmaline was in Paraíba State in Brazil. The first deposit was found in 1987 at Mina da Batalha. A few years later, similar material was found in two mines in Rio Grande do Norte State (Koivula and Kammerling, 1989).

- Since 2001, copper-bearing tourmaline from western Nigeria, very similar to the Brazilian material, has been available in the market. Production is scarce, and only small volumes currently reach the market (Abduriyim et al., 2006).

- Copper-bearing tourmaline was originally discovered in Mozambique in 1991 but only became widely known in 2005. Most of the production comes from secondary deposits, resulting in tumbled rough (Laurs et al., 2008). Mining was initially limited to artisanal miners, but larger operations were set up with variable degrees of success.

\section{Red and Pink Spinel}

- Red spinel was found alongside ruby in Luc Yen, Vietnam, in the 1980s. Large crystals are found in secondary gravels mined from small streams and under rice fields, as well as in primary hard rock mines, where the crystals are mined directly from the white marbles (Pardieu and Long, 2010).

- Mahenge, Tanzania, became the first widely known spinel deposit outside Asia. In the spring of 2007, four enormous spinel crystals (ranging from 5.7 to $52 \mathrm{~kg}$ ) were discovered in the Ipanko Valley, which produced many clean faceted stones in the double-digit range. Ever since there have been struggles over the mining licenses. Most of the production comes from small-scale operations (Hughes and Pardieu, 2011).

\section{Alexandrite}

- In the 1980s, alexandrites were found in Hematita, Minas Gerais, Brazil. This is the only modern location that has produced considerable volumes and qualities to date. After an artisanal miner rush, a larger-scale operation was developed, although this mine is small compared to some other colored stone mines (e.g., emerald mines). Other alexandrite deposits have been found in Brazil but are not as significant (Proctor, 1988).

- Indian alexandrite has been known since the 1980s (Bank, 1987; Durlabhji, 1999; Panjikar and Ramchandran, 1997). Only since 2000 has production become substantial at a few deposits. Mining is artisanal and often hindered by natural conditions, such as the intense rainy season or flooding due to the 2004 Indian Ocean tsunami.

- In recent decades, increased gemological knowledge and the discovery of large secondary deposits has led to alexandrites being recognized at several other important localities. They are occasionally found in Tunduru (Tanzania), Mogok (Myanmar), Sri Lanka, and Ilakaka (Madagascar). Anecdotal occurrences associated with emerald mineralization have been documented in Tanzania (Bank and Gübelin, 1976; Schmetzer and Malsy, 2011), Zimbabwe (Bank, 1964; Schmetzer et al., 2011), and Zambia.

\section{FIELD GEMOLOGY CASE STUDIES}

Working with Different Degrees of Reliability: Ethiopian Emeralds. In December 2016, the first highquality Ethiopian emeralds began circulating in the Bangkok market. Some parcels were also available in California. GIA was able to analyze some of these goods (F-type samples) to obtain preliminary data such as inclusion photomicrographs and trace element chemistry. When we analyzed the research samples, we found that their characteristics were identical to two client-submitted stones that did not match our known emerald data from other locations.

In the following months, more Ethiopian samples from other independent traders were acquired, and in March 2018 GIA visited the mining area and collected emeralds under the most reliable conditions (A- to D-type). The data from these samples were 


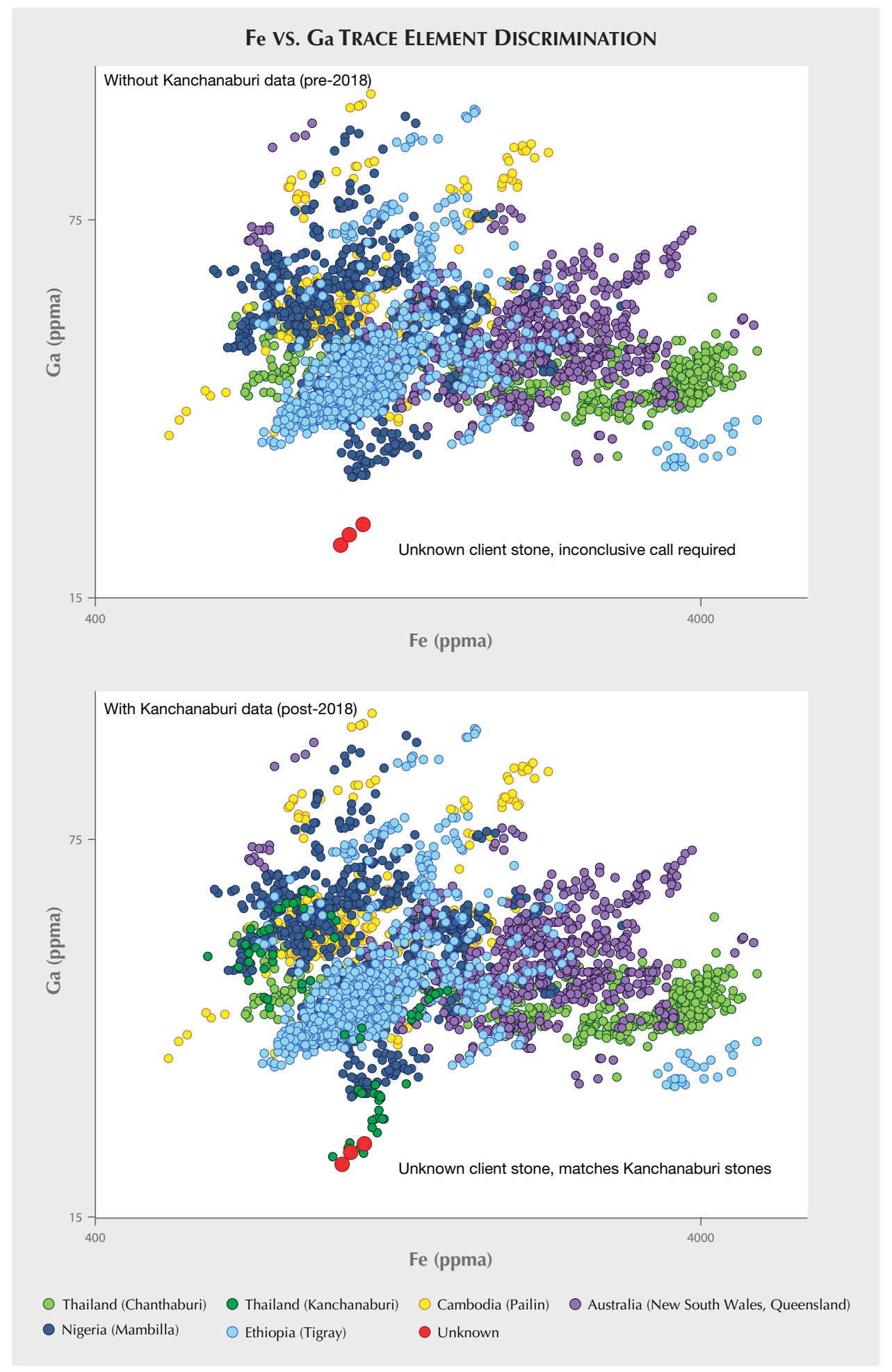

Figure 25. Trace element data of an unknown client stone compared to reference data in an Fe vs. Ga plot. Before the Kanchanaburi reference stones were analyzed, this stone did not match anything in GIA's database (top). However, a Thai origin determination was supported once the Kanchanaburi data were added (bottom).

compared with our preliminary data, and the data sets have been combined. The data collected on the new A- to D-type samples were also consistent with the first samples we studied, confirming the reliability of those F-type samples.
The Importance of Revisiting Old Sources: Kanchanaburi Sapphires. For years GIA analyzed magmatic sapphires with chemistry unlike any of the reference collection's magmatic sapphire stones. These unusual stones had much lower Ga content 


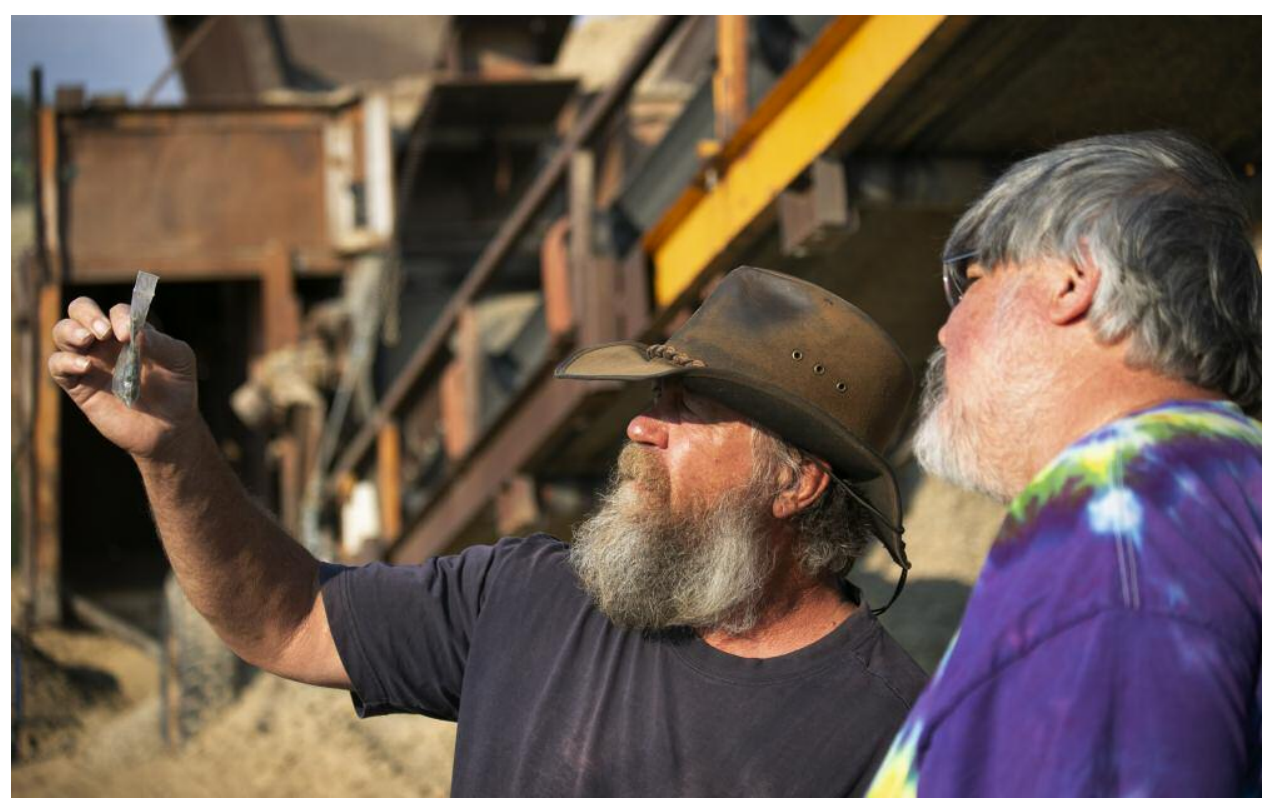

Figure 26. Shane McClure (right) and miner Russ Thompson examine sapphire samples from the Eldorado Bar of the Missouri River in Helena, Montana. Photo by Nathan Renfro.

and could have been mistaken for metamorphic-type sapphires based only on chemistry. In 2017, GIA's field gemology team visited the old mines near Kanchanaburi in western Thailand. According to all published reports, they had been closed since the late 1990s, but the field visit found them still producing sapphires. The team had never visited this mine because it was considered exhausted long before GIA's field gemology department came into existence. When we eventually tested these sapphires, many of them matched the mystery stones with low Ga content that were coming through the lab (figure 25). GIA can now confidently issue origin determinations on such stones rather than an "inconclusive" origin on laboratory reports.

Future Projects: Unknown Paraíba Tourmaline. GIA's identification laboratories sometimes analyze Paraíba tourmalines with a chemical composition that does not match any of our reference data. We have not yet succeeded in matching them to any reliable reference stones. We have, however, invested significant resources in obtaining reference samples from known sources that will match these mystery stones. One of the major goals of the field gemology program is to return to the different Paraíba tourmaline mining areas in Brazil and Africa in order to identify the mine that produced these unknown stones.

\section{VALUE OF THE COLLECTION FOR THE FUTURE}

GIA's colored stone reference collection has been built with an eye on origin determination, which means that the highest priority is certainty of provenance. Knowing the stones' enhancement history (if any) also makes them valuable for treatment experiments such as spectroscopic evaluation of blue sapphire before and after heat treatment.

The focus is currently on ruby, sapphire (figure 26), and emerald, as these are the most important stones we see in the lab. But other associated minerals are also collected. Most of these other materials have not been a focus of our research until now, but they might prove valuable in the future as localities become inaccessible or exhausted. Many of the mining sites we visit for ruby, sapphire, and emerald also produce other gem species, and to not collect these materials would be a wasted opportunity. For example, the Russian demantoid deposits and emerald deposits are both located near Ekaterinburg, making it convenient to visit both sites in a single field expedition. As another example, the Longido ruby mines and the Merelani tanzanite mines are both less than half a day from Arusha, so it would be logical to visit them both during an expedition to Tanzania.

Many deposits often produce more than one variety, such as Mogok, which supplies more red spinel than blue sapphire and ruby combined. Looking ahead to the future, gemstone varieties other than the big three should be collected for future projects involving origin determination, treatments, and so on.

During our expeditions, we collect detailed information about the source. Natural conditions, cultural customs, socioeconomic situations, challenges, 
mining conditions, and the like are all observed and documented with photos, videos, and interviews. This information is valuable not only for education but also to provide context about the gemstones for the trade and the public.

Other laboratories agree that a reliable origin collection is the only way to deliver high-quality re- search on origin determination (Gübelin Gemmological Laboratory, 2006). GIA's field gemology collection is one of the largest and most complete collections designed with origin determination in mind. Its value for gemological research and education cannot be underestimated and makes field gemology a truly remarkable part of GIA.

\section{ABOUT THE AUTHORS}

Mr. Vertriest is supervisor of GIA's field gemology department in Bangkok. Dr. Palke is senior research scientist, and Mr. Renfro is manager of identification (colored stones), at GIA in Carlsbad, California.

\section{ACKNOWLEDGMENTS}

GIA's field gemology efforts were initiated by Andy Lucas and Vincent Pardieu, who visited many gemstone mining areas on behalf of GIA's education and laboratory services, respectively. The networks, libraries, and procedures they developed formed the foundation of GIA's current field gemology department. We would like to take this opportunity to thank anyone who has helped GIA during field expeditions around the world, whether it was a simple introduction or full logistic support during a mine visit. And last, we appreciate the warm reception from gemstone miners, traders, and mining communities around the world during our expeditions.

\section{REFERENCES}

Abduriyim A., Kitawaki H., Furuya M., Schwarz D. (2006) "Paraíba"-type copper-bearing tourmaline from Brazil, Nigeria, and Mozambique: Chemical fingerprinting by LA-ICP-MS. $G \uplus G$, Vol. 42, No. 1, pp. 4-21, http://dx.doi.org/10.5741/ GEMS.42.1.4

Bank H. (1964) Alexandritvorkommen in Südrhodesien. Zeitschrift der Deutschen Gesellschaft fur Edelsteinkunde, Vol. 47, pp. 11-15.

— (1987) Alexandrite from India. Deutsche Goldschmiede Zeitung, Vol. 3, p. 116

Bank H., Gübelin E. (1976) Das Smaragd-Alexandritvorkommen von Lake Manyara/Tansania. Zeitschrift der Deutschen Gemmologischen Gesellschaft, Vol. 25, No. 3, pp. 130-147.

Bowersox G.W., Snee L.W., Foord E.E., Seal R.R. (1991) Emeralds of the Panjshir Valley, Afghanistan. GせG, Vol. 27, No. 1, pp. 26-39, http://dx.doi.org/10.5741/GEMS.27.1.26

Bridges C. (1982) Gems of East Africa. In D.M. Eash, Ed., Proceedings of the First International Gemological Symposium. Gemological Institute of America, Santa Monica, CA, pp. 266275.

Burlakov A., Burlakov E. (2018) Emeralds of the Urals. InColor, No. 40, pp. 88-94.

Dirlam D.M., Misiorowski E.B., Tozer R., Stark K.B., Bassett A.M. (1992) Gem wealth of Tanzania. Gせ G, Vol. 28, No. 2, pp. 80 102, http://dx.doi.org/10.5741/GEMS.28.2.80

Durlabhji M. (1999) Indian gemstones update. Gemworld, Vol. 26, No. 3, pp. 18-20.

Emmett J.L. (1999) Gem News: An update on the John Saul ruby mine. $G \uplus G$, Vol. 35, No. 4, pp. 213-215.

Gübelin E.J. (1982) Gemstones of Pakistan: Emerald, ruby and spinel. GÆG, Vol. 18, No. 3, pp. 123-129, http://dx.doi.org/ 10.5741/GEMS.18.3.123

Gübelin Gemmological Laboratory (2006) A holistic method to determining gem origin. Jewellery News Asia, No. 264, pp. $118-126$.

Gunawardene M., Chawla S.S. (1984) Sapphires from Kan- chanaburi Province, Thailand. Journal of Gemmology, Vol. 19, No. 3, 228-239.

Hsu T., Lucas A., Kane R.E., McClure S.F., Renfro N.D. (2017) Big Sky Country sapphire: Visiting Montana's alluvial deposits. $G \uplus G$, Vol. 53, No. 2, pp. 215-227, http://dx.doi.org/10.5741/ GEMS.53.2.215

Hughes R.W., Pardieu V. (2011) Gem hunting in Tanzania. www.lotusgemology.com/index.php/library/articles/147downtown-gem-hunting-in-tanzania

Hughes R.W., Pardieu V., Schorr D. (2006) Sorcerers \& sapphires: A visit to Madagascar. https://www.ruby-sapphire.com/index. $\mathrm{php} /$ component/content/article/10-articles/879-madagascarruby-sapphire? Itemid $=202$

Hughes R.W., Manorotkul W., Hughes E.B. (2017) Ruby Æ) Sapphire: A Gemologist's Guide. RWH Publishing, Bangkok.

Jennings R.H., Kammerling R.C., Kovaltchouk A., Calderon G.P., Baz M.K.E., Koivula J.I. (1993) Emeralds and green beryls of Upper Egypt. GÆG, Vol. 29, No. 2, pp. 100-115, http://dx.doi.org/10.5741/GEMS.29.2.100

Johnson M.L., Koivula J.I., Eds. (1997) Gem News: Origin of ancient Roman emeralds. Ge) G, Vol. 33, No. 4, p. 303.

Kiefert L., Schmetzer K., Krzemnicki M.S., Bernhardt H.-J., Hänni H.A. (1996) Sapphires from Andranondambo area, Madagascar. Journal of Gemmology, Vol. 25, No. 3, pp. 185-209.

Koivula J.I., Kammerling R.C., Eds. (1989) Gem News: Paraíba tourmaline update. $G \notin G$, Vol. 25, No. 4, p. 248.

Koivula J.I., Kammerling R.C., Eds. (1990) Gem News: Update on sapphire mining in Kanchanaburi. $G \uplus G$, Vol. 26, No. 4, pp. 302-303.

Koivula J.I., Kammerling R.C., Fritsch E., Eds. (1993) Gem News: Update on Monghsu ruby. GÆG, Vol. 29, No. 4, pp. 286-287.

Laurs B.M., Zwaan J.C., Breeding C.M., Simmons W.B., Beaton D., Rijsdijk K.F., Befi R., Falster A.U. (2008) Copper-bearing (Paraíba-type) tourmaline from Mozambique. GeG, Vol. 44, No. 1, pp. 4-30, http://dx.doi.org/10.5741/GEMS.44.1.4

Lucas A. (2012) Brazil's emerald industry. GÆG, Vol. 48, No. 1, 
pp. 73-77, http://dx.doi.org/10.5741/GEMS.48.1.73

Panjikar J., Ramchandran K.T. (1997) New chrysoberyl deposits from India. Indian Gemmologist, Vol. 7, No. 1-2, pp. 3-7.

Pardieu V. (2014) Hunting for "Jedi" spinels in Mogok. GÆ)G, Vol. 50, No. 1, pp. 46-57, http://dx.doi.org/10.5741/GEMS.50.1.46

Pardieu V. (2018) "Ants and kings": Emeralds from Mananjary, Madagascar. https://www.youtube.com/watch?v=qUioeFyvY_o

Pardieu V. (2019) Thailand: The undisputed ruby trading kingdom: A brief history. InColor, Vol. 42, pp. 14-22.

Pardieu V., Farkhodova T. (2019) Spinel from Tajikistan: The gem that made famous the word "ruby." InColor, No. 43, pp. 3033.

Pardieu V., Long P.V. (2010) Gem News International: Ruby, sapphire, and spinel mining in Vietnam: An update. $G \uplus G$, Vol. 46, No. 2, pp. 151-152.

Pardieu V., Rakotosaona N. (2012) Ruby and sapphire rush near Didy, Madagascar. GIA Research News, https://www.gia.edu/ gia-news-research-nr101512

Pardieu V., Jacquat S., Bryl L.P., Senoble J.B. (2009) Rubies from northern Mozambique. InColor, No. 12, pp. 32-36.

Pardieu V., Dubinsky E.V., Sangsawong S., Chauviré B. (2012) Sapphire rush near Kataragama, Sri Lanka. GIA Research News, https://www.gia.edu/ongoing-research/sapphire-rush-nearkataragama-sri-lanka

Pardieu V., Sangsawong S., Muyal J., Sturman N. (2014) Blue sapphires from the Mambilla Plateau, Taraba State, Nigeria. GIA Research News, www.gia.edu/gia-news-research-nigeriansource-blue-sapphire

Pardieu V., Sangsawong S., Detroyat S. (2015) Gem News International: Rubies from a new deposit in Zahamena National Park, Madagascar. Ge G, Vol. 51, No. 4, pp. 454-456.

Pardieu V., Sangsawong S., Vertriest W., Detroyat S., Raynaud V., Engniwat S. (2016) Gem News International: Blue sapphires from a new deposit near Andranondambo, Madagascar. $G \uplus G$, Vol. 52, No. 1, pp. 96-97.

Pardieu V., Vertriest W., Weeramonkhonlert V., Raynaud V., Atikarnsakul U., Perkins R. (2017) Sapphires from the gem rush Bemainty area, Ambatondrazaka (Madagascar). GIA Research News, www.gia.edu/gia-news-research/sapphires-gem-rushbemainty-ambatondrazaka-madagascar

Peretti A., Schmetzer K., Bernhardt H.-J., Mouawad F. (1995) Rubies from Mong Hsu. GeG, Vol. 31, No. 1, pp. 2-26, http://dx.doi.org/10.5741/GEMS.31.1.2

Proctor K. (1988) Chrysoberyl and alexandrite from the pegmatite districts of Minas Gerais, Brazil. Gせ G, Vol. 24, No. 1, pp. 1632, http://dx.doi.org/10.5741/GEMS.24.1.16

Renfro N., Sun Z., Nemeth M., Vertriest W., Raynaud V., Weeramonkhonlert V. (2017) Gem News International: A new discovery of emeralds from Ethiopia. $G \uplus G$, Vol. 53, No. 1, pp. 114-116.

Renfro N.D., Palke A.C., Berg R.B. (2018) Gemological characterization of sapphires from Yogo Gulch, Montana. GÆ G, Vol. 54, No. 2, pp. 184-201, http://dx.doi.org/10.5741/GEMS.54.2.184
Schmetzer K. (2010) Russian Alexandrites. Schweizerbart Science Publishers, Stuttgart, Germany.

Schmetzer K., Malsy A.-K. (2011) Alexandrite and colour-change chrysoberyl from the Lake Manyara alexandrite-emerald deposit in northern Tanzania. Journal of Gemmology, Vol. 32, No. 5-8, pp. 179-209.

Schmetzer K., Bernhardt H.J., Biehler R. (1991) Emeralds from the Ural Mountains, USSR. $G \oplus G$, Vol. 27, No. 2, pp. 86-99, http://dx.doi.org/10.5741/GEMS.27.2.86

Schmetzer K., Malsy A.-K., Stocklmayer V., Stocklmayer S. (2011) Alexandrites from the Novello alexandrite-emerald deposit, Masvingo District, Zimbabwe. Australian Gemmologist, Vol. 24, No. 6, pp. 133-147.

Schwarz D., Schmetzer K. (2001) Rubies from the Vatomandry area, eastern Madagascar. Journal of Gemmology, Vol. 27, No. 7, pp. 409-416.

Schwarz D., Petsch E.J., Kanis J. (1996) Sapphires from the Andranondambo region, Madagascar. $G \uplus G$, Vol. 32, No. 2, pp. 8099, http://dx.doi.org/10.5741/GEMS.32.2.80

Schwarz D., Kanis J., Schmetzer K. (2000) Sapphires from Antsiranana Province, northern Madagascar. $G \notin G$, Vol. 36, No. 3, pp. 216-233, http://dx.doi.org/10.5741/GEMS.36.3.216

Schwarz D., Pardieu V., Saul J.M., Schmetzer K., Laurs B.M., Giuliani G., Klemm L., Malsy A.-K., Erel E., Hauzenberger C., Du Doit G., Fallick A.E., Ohnenstetter D. (2008) Rubies and sapphires from Winza, central Tanzania. Ge G, Vol. 44, No. 4, pp. 322-347, http://dx.doi.org/10.5741/GEMS.44.4.322

Sir David Attenborough on Museum Collections - 360 (2017) American Museum of Natural History, August 31, https://www.amnh.org/explore/videos/at-the-museum/sirdavid-attenborough-on-museum-collections-360

Smith C.P. (1998) Rubies and pink sapphires from the Pamir Mountain Range in Tajikistan, former USSR. Journal of Gemmology, Vol. 26, No. 2, pp. 103-109.

Thomas T., Rossman G.R., Sandstrom M. (2014) Device and method of optically orienting biaxial crystals for sample preparation. Review of Scientific Instruments, Vol. 85, No. 9, 093105, http://dx.doi.org/10.1063/1.4894555

Trivier A. (2018) Between rice paddies and karst pinnacles: The Luc Yen gemstone mining area. InColor, No. 39, pp. 16-26.

Vertriest W., Saeseaw S. (2019) A decade of ruby from Mozambique: A review. Ge G, Vol. 55, No. 2, pp. 162-183, http://dx.doi.org/ 10.5741/GEMS.55.2.162

Vertriest W., Weeramonkhonlert V., Raynaud V., Bruce-Lockhart S. (2017) Gem News International: Sapphires from northern Ethiopia. Ge G, Vol. 53, No. 2, pp. 247-248.

Zoysa E.G., Rahuman S. (2012) Sapphire rush in Kataragama. InColor, No. 19, pp. 56-61.

Zwaan J.C., Seifert A.V., Vrána S., Laurs B.M., Anckar B., Simmons W.B., Falster A.U., Lustenhouwer W.J., Muhlmeister S., Koivula J., Garcia-Guillerminet H. (2005) Emeralds from the Kafubu area, Zambia. GÆG, Vol. 41, No. 2, pp. 116-148, http://dx.doi.org/10.5741/GEMS.41.2.116 